\title{
CONSTRUÇÃO E CRÍTICA NA NOVA SOCIOLOGIA FRANCESA
}

\author{
Frédéric Vandenbergue*
}

Resumo: Este artigo propõe uma análise comparativa das sociologias de Bourdieu, Boltanski/Thévenot e Latour/Callon. Seguindo uma dialética descendente, das estruturas materiais Bourdieu às alturas ideais de Boltanski e Thévenot e às platitudes de Latour e Callon, o autor expõe em um primeiro tempo o estruturalismo genético de Bourdieu como um pensamento racional e relacional, que estabelece uma prioridade às estruturas. Ele mostra que o desvio objetivista da teoria dos campos e dos habitus tende a esvaziar as capacidades reflexivas de que dispõem os atores e a reduzi-los a simples agentes. Em um segundo momento, o autor mostra que a sociologia da crítica de Boltanski e Thévenot permite retificar ou corrigir a sociologia crítica. Ela introduz, firmemente, as mediações simbólicas que são as Cidades e concebe os Dispositivos como comutadores, que restabelecem o laço com a macrossociologia. Enfim, em um terceiro e último momento, o autor critica a eliminação das estruturas materiais e ideais que configuram a ação para a sociologia dos atores em rede. Ela se fixa nas práticas que performam o mundo, associando os humanos e os não humanos, em um tecido sem costura e sem fim que cobre o mundo.

Palavras-chave: Bourdieu, Boltanski, Latour, sociologia crítica, sociologia pragmática, teoria dos atores em rede, construção social, crítica.

A partir de uma comparação lógica de diversas formulações e articulações das noções centrais de "construção" e de "crítica",

\footnotetext{
* Fréderic Vandenberghe é pesquisador em sociologia na Universidade de Estudos Humanistas, nos Países Baixos. Ensinou nos Estados Unidos, na Inglaterra e no Brasil.

Taduzido do original francês por Ana Liési Thurler.

Artigo recebido em 6 maio 2005; aprovado em 5 out. 2005.
} 
gostaria de submeter a "sociologia crítica" de Pierre Bourdieu, a "sociologia pragmática" de Luc Boltanski e Laurent Thévenot e a "sociologia das redes sociotécnicas" de Bruno Latour e Michel Callon ao exercício um tanto escolar da comparação triangular ("comparai e contrastai..."). ${ }^{1}$ Apesar do "clima de família", aproximando os diferentes matizes da crítica e da construção sociais que encontramos entre as novas sociologias francesas, os protagonistas, tanto quanto os comentadores da vida intelectual parisiense (Chateauraynaud, 1991; Corcuff, 1995; Dosse, 1995; Bénatouïl, 1999), freqüentemente compararam a sociologia pragmática e a sociologia das redes sociotécnicas, sem dúvida para melhor refletir sobre as variações com a sociologia crítica de Bourdieu contra as quais elas foram explicitamente construídas. Vistas do exterior, as continuidades e as convergêncas entre a sociologia crítica e a sociologia pragmática são, entretanto, tão consideráveis quanto as divergências, separando a sociologia interpretativa de Boltanski e Thévenot, da sociologia experimental de Latour e Callon.

Ao dizer isso, de forma alguma minimizo a importância da "mudança de paradigma" dos anos 80 (Gauchet, 1988), mas à medida em que isso ocorre contra o "pensamento de 68 " e, portanto, contra o estruturalismo genético de Bourdieu, eu me pergunto se uma leitura mais simpática e menos reducionista, que tente abrir o sistema bourdieuniano desde o interior, pensando "com Bourdieu contra Pierre Bourdieu" (Passeron) não seria mais apropriado para se desenvolver uma sociologia crítica 'post-bourdieuniana' que não seja, simplesmente, anti-bourdieuniana. Além disso, mantendo a continuidade entre a sociologia crítica e seus críticos, essa aproximação permitiria abrir a via a uma correção mútua que, no lugar de quebrar o bastão, como dizia Mao, toma-o ao meio para restabelecer a comunicação e tentar construir uma teoria crítica da sociedade.

\section{Crítica e construção}

Nos anos 80, vimos emergir na Inglaterra (Giddens, Bhaskar, Archer), na Alemanha (Habermas, Luhmann, Beck), nos Estados 
Unidos (Collins, White, Alexander), na França e no Canadá (Bourdieu, Freitag) um "novo movimento teórico", procurando superar de maneira sistemática a oposição entre a micro e a macrossociologia que dividiu a sociologia pós-parsoniana desde o pós-guerra (Vandenberghe, 2004). À medida que as novas sociologias francesas se esforçam para sair das antinomias e ambigüidades herdadas da filosofia (sujeito-objeto, ideal-material, individualcoletivo, micro-macro) para uma reconstrução desfetichizante da gênese do objetivo, elas podem ser ditas 'construtivistas', no sentido amplo do termo (Corcuff, 1995).

A fim de introduzir um mínimo de clareza conceitual na noite construtivista e escapar dos amálgamas fáceis do construtivismo radicalmente chique além-Atlântico, assim como às complexidades do construtivismo sistêmico além-Reno, gostaria de distinguir, e rapidamente apresentar, três constelações intelectuais na galáxia do construtivismo social que influenciaram as novas sociologias francesas: a constelação fenomenológica, a dialética e a estruturalista.

A primeira versão do construtivismo - mais orientada para uma microssociologia - tem suas origens na fenomenologia da constituição de Edmund Husserl. Analisando minuciosamente as operações cognitivas pelas quais o mundo comum de significações ou de experiências vividas é, intencionalmente, constituído pela consciência transcendental (Husserl) ou mundana (Schütz) como 'mundo' -, o construtivismo fenomenológico reúne o problema do consenso, pela perspectiva das teorias do contrato social e da comunicação. Com isso, se opõe à segunda versão do construtivismo: a versão macrossociológica e dialética, de inspiração marxista hegeliana ou weberiana que, na esteira de Lukács e Mannheim, cerca as determinações existenciais e sociais dos sistemas de pensamento para os descobrir ou, conforme o caso, os superar em uma síntese englobante. Substituindo o termo fenomenológico da 'constituição' pelo da 'construção', Berger e Luckmann (1967) forjaram uma aliança entre os dois construtivismo em The Social Construction of Reality, abrindo assim uma via de construções sociais e de desconstruções 
textuais de tudo, processos caracterizadores da sociologia das ciências pós-blooriana, na qual a teoria das redes sociotécnicas constitui a linha de ruptura mais radical. Insistindo sobre o caráter arbitrário dos sistemas de representações sociais, pode-se fazer remontar à terceira versão do construtivismo a sociologia das formas de classificação de Durkheim e Mauss e religá-la, passando por Saussure e LéviStrauss, ao modo desconstrutivista dos pós-estruturalistas acolhidos e revistos pelo pós-modernismo, os cultural studies e o feminismo diferencialista, designado como a terceira onda.

Quando Bourdieu tentou integrar as três variantes do construtivismo social em uma teoria neo-kantiana do conhecimento sociológico que rompe, em um primeiro momento, com a constituição do mundo ordinário pelo senso comum para, em um segundo momento, reintegrá-lo, dialeticamente, em uma fenomenologia crítica da constituição dóxica do mundo, Latour desfez a síntese bourdieuniana, radicalizando e pós-modernizando o construtivismo constitutivo dos etnometodólogos, enquanto Boltanski e Thévenot desenvolveram uma versão original e pluralista do construcionismo constitutivo-consensual, a partir de um desvio pragmático da sociologia crítica. Nas páginas que seguem, apresentarei as versões respectivas em termos da construção estrutural do objeto, da constituição pragmática do mundo comum e da co-construção performativa do mundo e das redes sociotécnicas.

As novas sociologias francesas não são somente construtivistas. São, igualmente, a um título ou a outro, críticas. Tanto quanto a noção de 'construção', a noção de 'crítica' é polissêmica e, facilmente, presta-se a confusão. No que concerne às ciências sociais, convém distinguir a crítica epistemológica da sociologia da crítica social da sociedade, mesmo que em uma teoria crítica da sociedade se deva combiná-las, perseguindo sistematicamente as reificações e as alienações (Vandenberghe, 1997-1998). ${ }^{2}$ A crítica epistemológica remonta evidemente à Crítica da razão pura de Kant. Tratando das condições de possibilidade do conhecimento, ela busca manter o conhecimento no interior dos limites da razão e analisa transcendentalmente como as categorias do pensamento sintetizam 
a multiplicidade empírica. Reconduzido ao terreno do conhecimento sociológico, a crítica epistemológica gira em torno da questão do naturalismo e se dedica a denunciar a redução da ação significativa ao comportamento, assim como a hipóstase dos conceitos e das abstrações, como o Estado, a Igreja ou a Sociedade, que o sociólogo toma como realidades que agiriam como pessoas.

Emergindo não da epistemologia, mas da ideologia, a crítica social que julga e condena, protesta e denuncia as injustiças em nome de ideais e de grandes princípios pode ser considerada como a forma reflexiva e articulada das denúncias espontâneas da vida cotidiana ou, como diz belamente Michael Walzer (1987, p. 65), ‘o primo educado do lamento ordinário'. Na filosofia política e moral contemporânea, podemos assinalar ao menos quatro tradições vivas da crítica social e, portanto, de modos pós-metafísicos para fundar os julgamentos proferidos: a tradição racionalista da 'invenção', a tradição romântica da 'interpretação', a tradição hegeliana da 'reconstrução' e a tradição cética da 'desconstrução' .

$\mathrm{Na}$ tradição kantiana, tal como a encontramos atualizada em nossos dias por John Rawls, os critérios de julgamento são racionalmente deduzidos dos procedimentos normativos determinados pela teoria mesma e inventados, independentemente do contexto sócio-historico. Na tradição romântica e hermenêutica, representada por Michael Walzer e Charles Taylor, a crítica se apóia sobre as normas e os valores em vigor no interior de uma comunidade dada e por meio dos quais ela 'interpreta' e explicita as representações da justiça. Se o modelo romântico permanece ligado ao chão da comunidade, o modelo dialético o ultrapassa, integrando o universalismo da 'invenção' e o contextualismo da 'interpretação' em uma síntese superior. No 'modelo reconstrutivo', característico da tradição hegeliano-marxista - notadamente a Escola de Frankfurt (incluindo aí Habermas e Apel) -, os critérios de julgamento estão, em parte, já realizados e incorporados nas instituições existentes, mesmo transcendendo-os, oferecendo assim sólidos padrões para uma 'crítica imanente'. Enfim, o modelo genealógico de procedência nietzschiana, no qual a crítica intempestiva de foucaltianos e 
deleuzianos se inspira amplamente, atacando a todos os modelos precedentes sob pretexto de que toda visão normativa da sociedade é repressiva e só poderá, cedo ou tarde, se tornar justificadora da exclusão e da dominação.

Quando a teoria crítica de Bourdieu, ao mesmo tempo, ataca aqueles que hipostasiam o substantivo em substância e se apóia sobre a tradição hegeliano-marxista para denunciar as injustiças da dominação de classe, Boltanski e Thévenot criticam a teoria crítica pela arrogância epistemológica e normativa e, permanecendo atentos ao cerne da situação, procuram explicitar o sentido da justiça e reconstruir a gramática dos atos de justificação da qual os atores dão prova quando denunciam uma injustiça. Desconstruindo alegremente todas as oposições legadas pela tradição filosófica e sociológica, Latour adota facilmente a postura nietzschiana, se fazendo o portavoz das coisas excluídas da constituição moderna e propõe uma nova ontologia experimental com ressonâncias universais. Nas próximas páginas, apresentarei as respectivas versões da crítica que encontramos na nova sociologia francesa, com os deslocamentos sucessivos da sociologia crítica à sociologia da crítica e à crítica da sociologia.

A comparação lógica entre as três sociologias será apresentada aqui como um declive progressivo de uma visão do alto para uma visão no nível da realidade social (Vandenberghe, 2002, p. 59-62). Do mundo tridimensional da sociologia durkheimniano-marxista de Bourdieu com essas figurações relacionais e materiais que sobredeterminam as estruturas simbólicas, assim como as ações e as interações, passaremos a seguir ao mundo bidimensional da sociologia weberiano-durkheimniana de Boltanski e Thévenot na qual as ações em situação de pessoas particulares são coordenadas e mediatizadas pelas convenções gerais superiores, para chegar, ao final do percurso, ao mundo plano, terra-a-terra, da sociologia serresianodeleuziana de Latour e Callon com os encadeamentos rizomáticos de seres humanos e não humanos. Essa comparação lógica das novas sociologias é concebida como uma etapa na construção de uma teoria dialética da sociedade que integra, dialeticamente, o 
momento hermenêutico no interior das estruturas de dominação e reconfigura a teoria dos atores em rede em uma teoria crítica do mundo presente.

\section{Sociologia crítica: a construção estrutural do objeto como sistema relacional}

Em seu ensaio póstumo de auto-socioanálise, lançado primeiramente na Alemanha, Pierre Bourdieu (2002) conta como, retornando da Argélia, conheceu uma verdadeira 'conversão' da filosofia à etnologia e à sociologia antes de mergulhar em uma pesquisa sociológica de campo que transpôs as noções filosóficas por meio da sociologia empírica para retomá-las, em última análise, contra a filosofia mesma. Religando sistematicamente as noções veneráveis de 'campo', 'habitus' e de 'violência simbólica', ele desenvolveu, em um período de poucos anos (1966-1972), uma 'grande teoria' unitária, total e superfortificada do mundo social, capaz de superar, ou melhor, de eliminar a antinomia da ação e da estrutura, em uma teoria construtivista neo-objetivista das práticas de reprodução sociais. Retrospectivamente, nos damos conta de que a totalidade de suas pesquisas ulteriores sobre os campos (e os subcampos) da produção e da consumação culturais, encontrando sua origem na formulação precoce de uma teoria sociológica neokantiana do conhecimento que integre o racionalismo de Bachelard com o relacionismo de Cassirer para, em seguida, transpor o pensamento racionalista e relacional das ciências naturais para as ciências sociais (Vandenberghe, 1999).

Em A profissão de sociólogo, Bourdieu e seus colegas apresentam uma versão forte da teoria do conhecimento sociológico, entendido como "sistema dos princípios que definem as condições de possibilidade de todos os atos e de todos os discursos propriamente sociológicos e somente destes" (Bourdieu; Chamboredon; Passeron, 1973, p.15-16 [1999, p. 13]; Bourdieu, 1968, p. 681682). ${ }^{4}$ Funcionando como uma verdadeira embreagem da teoria do 
campo e do habitus científico-sociológico, a teoria do conhecimento sociológico - sistema de esquemas mais ou menos dominados pela interiorização da teoria e aplicação repetida de seus princípios abstratos em uma pesquisa de campo concreta, determina que o sociólogo conquiste o fato científico contra o senso comum - é o momento bachelardiano da 'ruptura epistemológica' -, e construa o sistema completo de relações objetivas sobre-determinando a manifestação empírica do objeto, tal como ele se dá à observação - é o momento cassireriano da construção do objeto científico como estrutura relacional.

Aplicando conscienciosamente o método estrutural, o sociólogo se dispõe a objetivar a realidade social como um sistema de relações entre pessoas e a compreender a posição (e as tomadas de posição) de cada pessoa no interior de uma configuração que a coloca em relação com todas as outras posições (e tomadas de posição) e lhe confere seu sentido objetivo, permitindo assim explicar o sentido das ações a partir da rede completa de relações, nas quais e pelas quais as ações se realizam. Ainda que a construção do objeto crie um impasse sobre a ordem de interações e as considere do alto como uma emanação de posições estruturais que os atores ocupam no campo, ela, de fato, introduz uma terceira dimensão na análise social, o primeiro nível sendo constituído pelas práticas, o segundo pela ordem de interação, e a terceira envolvendo e sobredeterminando os dois níveis inferiores, pelo sistema estrutural de relações entre as posições sociais dos atores no campo.

A construção sociológica do objeto científico como sistema de relações objetivas, nas quais os indivíduos se encontram inseridos como uma partícula em um campo energético, coincide com o momento objetivista e determinista da explicação científica própria de cada ciência. Em sociologia, o princípio determinista da 'razão suficiente' toma a forma do 'princípio de não transparência dos fatos sociais', princípio aceito explícita (Durkheim, Marx) ou implicitamente (Weber) por todos os sociólogos, segundo o qual a vida social não deve ser explicada pela consciência dos indivíduos, 
mas pelas causas profundas que escapam à consciência e explicam os fatos empiricamente observados. Cada vez que remetemos os fatos sociais a explicações psicológicas ou interacionais, simplesmente invertemos as causas e os efeitos. O professor do Collège de France não deixa subsistir qualquer dúvida a esse respeito: "É a estrutura das relações constitutivas do espaço do campo que comanda a forma que pode revestir as relações visíveis da interação e o conteúdo mesmo da experiêcia que os agentes podem ter dela" (Bourdieu, 1982, p. 42).

Mas, se as causas estruturais explicam a coerência formal das ações e das interações, restam somente essas últimas para atualizar as estruturas profundas e torná-las visíveis em seus efeitos concretos, em uma situação de ação particular. Entre a estrutura do campo e as ações concretas que a reproduzem, Bourdieu faz intervir o habitus, definido como "sistema de disposições - orgânicas ou mentais - e de esquemas inconscientes de pensamento, de percepção e de ação" (citado por Boltanski, 1971, p. 209), que o indivíduo incorporou no transcorrer de sua existência. Funcionando como um "operador teórico", que dá uma coerência formal a ações materialmente muito diferentes, o habitus realiza, de fato, a ligação e a mediação entre o sistema invisível das relações estruturadas que formam o campo (pelas quais as ações são formadas) e as ações e interações visíveis dos atores (que estruturam e reproduzem as relações que formam o campo).

Se a construção do campo constitui o momento objetivista e determinista da análise, a explicação pelo habitus constitui seu momento subjetivista e genético, reintegrando o senso comum e as pré-noções, assim como as ações e as interações situadas na análise do campo. ${ }^{5}$ Compreendendo as ações e as interações situadas como produto das estruturas sociais interiorizadas, que regem a produção dos atos que, em certas circunstâncias bem específicas, reproduzem as estruturas das quais elas são o produto, Bourdieu integra dialeticamente a ação e a estrutura, o habitus e o campo, em um mesmo sistema de reprodução, superando, assim, a oposição entre o subjetivismo e o objetivismo, mas dando-lhe um 
deslocamento claramente objetivista. Forçando conscientemente a relação e minimizando o livre arbítrio dos atores, reduzidos a agentes, Bourdieu busca desvelar a exterioridade no coração da interioridade e a desfetichizar as determinações sociais que levam os atores a agir como o fazem. A liberdade não consistiria na negação dos determinismos, mas, como em Spinoza, no conhecimento que permite ao sujeito, em parte, se liberar dos determinismos e agir com os outros com conhecimento de causa para transformá-los. Saber para prever, prever para poder...

Ainda que Bourdieu assuma plenamente o deslocamento objetivista, esse deslocamento conduz a todo tipo de tensões que percorrem sua obra. Ele teria podido evitá-las se, no lugar de sublimar sua indignação moral em uma hiperviolência teórica e científica, ele tivesse acentuado mais as capacidades reflexivas de que dispõem os atores, em uma situação de ação ou de interação. Ele se recusou fazê-lo. Contrariamente a seus detratores - notadamente Jeffrey Alexander (2000) -, penso que sua arquitetura teórica e metateórica o permite. É suficiente ler Bourdieu com os óculos da teoria da estruturação de Anthony Giddens, como prelúdio à teoria do agir comunicacional de Habermas, para curvar a teoria da reprodução em uma direção mais voluntarista, capaz de pensar, ao mesmo tempo, a reprodução da sociedade e sua transformação, de tal modo que ela não apenas se efetua potencialmente em cada situação de ação e de interação, mas também nos momentos ocasionais de ruptura consciente e desejada com a ordem vigente. ${ }^{6}$

Pela limitação de espaço, penso destacar aqui somente algumas tensões na teoria bourdieuniana e indicar as inflexões necessárias para resolvê-las. Primeiro, a objetivação das estruturas objetivas permite tal privilégio epistemológico ao sociólogo, acabando ele por se separar dos membros ordinários da sociedade, quando é suficiente interpretar o desvelamento das estruturas como uma formalização dos atos de denúncia efetuados pelos membros e considerar, como o próprio Bourdieu (1980, p. 44) indica, "o trabalho teórico" do sociólogo como uma "forma particular" de teorização que encontramos no mundo vivido, para manter a continuidade entre os 
desvelamentos de uns e de outros. Nessa perspectiva - que é, aliás, a de Habermas (1968) -, animada por um "interesse de conhecimento emancipatório", a teoria crítica dá uma forma metódica à experiência do sofrimento, apontando a violência estrutural que está em sua origem.

A seguir, reatando com o 'postulado da adequação' de Schütz, a partir do qual as construções teóricas do sociólogo devem ser compreensíveis para os membros, não se restabelece somente a continuidade entre as teorizações de uns e de outros, mas pode-se também compreender melhor o efeito rebatido do desvelamento das estruturas exteriorizadas e interiorizadas da dominação. Mesmo se tal hermenêutica crítica somente é possível com a condição de que a reflexividade seja explicitamente reintroduzida no habitus (Kögler, 1997), a sociologia crítica a pressupõe, negando-a inteiramente. Enfim, se o sociólogo escreve para expor os determinismos que pesam sobre a ação e para, com isso, contribuir, para a formação de um sujeito autônomo, ele deve supor a interpenetrabilidade hermenêutica entre ciência e senso comum, aceitar que a reflexão teórica é eficaz e que as idéias podem mudar o habitus, se não o mundo.

Enfim, para evitar que o habitus funcione como o gênio maligno da reprodução, seria necessário insistir mais nas capacidades transformadoras do habitus, indicando que é sempre ativado em situações particulares. Entre as condições de ativação do habitus e sua realização em uma situação particular, há, em princípio, um espaço para uma reflexão, para um diálogo interno e - por que não? -, para uma comunicação racional, capaz de transformar aquilo pelo qual o habitus é determinado. Mesmo se o princípio dessa transformação se encontra na tensão entre a estrutura e o habitus, não há razão para não se supor que a intensidade e o sentido dessa tensão dependam da reflexão do ator cujas ações são determinadas, à medida que ele mesmo se determina em uma situação de ação particular e contingente. 


\section{Sociologia da crítica: a constituição pragmática do mundo comum, no regime da justificação}

Luc Boltanski, Laurent Thévenot e sociólogos, economistas e estatísticos - em ruptura com a sociologia crítica de Pierre Bourdieu, mas a partir de uma análise construtivista dos grupos sociais (Boltanski, 1982) e das categorias socioprofissionais (Desrosières; Thévenot, 1988), tributária de seus trabalhos sobre as classes e as classificações sociais -, trabalharam com eles no GSPM. No fio de suas pesquisas romperam com a crítica bourdieuniana da "ilusão ocasionalista" (Bourdieu, 1972, p. 184), relatando diretamente as práticas de propriedades inscritas na situação e se interessando pelas situações de ações e pelas interações enquanto tais, sem considerar a estrutura conjuntural em que elas ocorrem como simples epifenômenos da estrutura objetiva. Retomando uma metáfora aérea utilizada por Bernard Lahire (1996, p. 383) para teorizar a variação das escalas de análise e dos contextos de observação, poderíamos comparar a passagem da visão top down da macrossociologia bourdieuniana para a visão bottom up da microssociologia pragmática a uma descida de pára-quedas que mergulharia o observador no meio de ações e de interações, dando acesso, diretamente, à observação da vida social in situ.

Chegados ao campo da pesquisa, os autores De la justification observam os litígios, as disputas, as contendas, as cenas, as dificuldades, em suma, as discórdias de todo tipo, nas quais a grandeza relativa das pessoas é, publicamente, colocada em causa. A fim de analisar as operações críticas (denunciar, disputar, acusar, justificar, etc.) por eles observadas em situações concretas de disputa e submetidas a um imperativo de justificação, Boltanski e Thévenot construíram um modelo pragmático arquitetado na competência do julgamento que permite compreender como os atores manifestam seus desacordos sem recorrer à violência e justificam suas pretensões à justiça, se referindo a valores gerais (as 'Cidades') e se apoiando sobre objetos comuns (os 'Dispositivos'). 
Os teóricos da justificação renunciam à história de longa duração, incorporada nos corpos ou objetivada nos sistemas sociais, para se ligarem, resolutamente, ao presente imediato, ${ }^{7}$ recusando projetar as características estruturais na situação observada e ligálas aos atores dos atributos e das qualificações fixas herdadas do passado. Atentos ao cerne da situação, eles se situam resolutamente na tradição do pragmatismo americano e apresentam uma análise relacionada às sequências de ação e de disputa relativamente curtas, a fim de apreender as pressões situacionais, materiais e ideais, as operações de justificação (Dodier, 1991, 1993). Contrariamente ao teórico do habitus, eles não estão tão interessados pelo passado ou pelo futuro quanto pelo presente. O que lhes interessa não é o sistema, nem a estrutura, mas as ações e as práticas; não os atores nem os agentes, mas a situação; não os homens e as mulheres, mas seus momentos - moments and their men -, para retomar uma fórmula célebre de Goffman (1967, p. 3). Os 'momentos críticos' (Boltanski; Thévenot, 1991, p. 31) retêm mais particularmente sua atenção. Nesses momentos não habituais de crítica e de questionamento, os atores exprimem, publicamente, suas censuras e se voltam para a justiça.

Os antigos colaboradores de Bourdieu se mantêm na teoria neo-wittgensteiniana das práticas, mas, doravante, concebem-nas como práticas fora do campo e não-habitualizadas. Com Bourdieu, Giddens, Garfinkel e outros teóricos da prática (prática, até mesmo praxis), sustentam a tese ontológica segundo a qual a realidade social é, em última instância, composta de práticas situadas e distribuídas, incorporadas ou reflexivas, interligadas e coordenadas por entendimentos tácitos ou explícitos que estão no cadinho do mundo social e o constituem como mundo comum (Schatzki, 2001, p. 2-4). Enquanto princípios motores do mundo, as práticas são formadoras e constitutivas: elas subentendem e constituem os indivíduos, as ações, as interações, o mundo vivido, a linguagem, a cultura, as instituições, as organizações, as estruturas e os sistemas sociais. ${ }^{8}$ Sobre esse ponto, Boltanski e Thévenot se mantêm em acordo com a retomada de Wittgenstein por Bourdieu, ainda que eles se recusem doravante a envolver dialeticamente as práticas nas 
estruturas e nos sistemas, considerando-os, ao final da análise, como epifenômenos. Sem se permitir as facilidades de uma perspectiva oblíqua, eles eliminam as estruturas materiais que sobredeterminam o espaço de interações e incorporam o espaço tridimensional em um espaço em dois níveis, contendo, de um lado, pessoas particulares em interação, situadas com outras pessoas e objetos e, de outro lado, diferentes convenções gerais orientadas para um bem comum, permitindo definir a grandeza relativa das pessoas (Boltanski; Thévenot, 1991, p. 43, 46, 141, 244; Boltanski, 1990, p. 31, 67, 74; Boltanski; Chiapello, 1999, p. 409, 625).

Eliminando as estruturas materiais em benefício de suas estruturas ideais - as Cidades -, o desvio pragmático gira na direção do idealismo hermenêutico. Essa estratégia metateórica tem vantagens, mas apresenta também inconvenientes. A introdução das convenções normativas permite romper com a visão reificada e desencantada da sociedade, como um sistema de relações entre as posições sociais (o campo), cujos atores atualizam as pressões, bucando seus interesses em situação de dominação. Uma vez que o sociólogo rompe com o postulado da determinação da ação pelas estruturas materiais de dominação e aceita que os atores sejam motivados por idéias, por normas e por valores, ele pode escapar, ao mesmo tempo da visão determinista e materialista das estruturas sociais, e a seu complemento, da visão utilitarista e estratégica das ações que a acompanha. Bourdieu permaneceu ligado a uma análise um pouco circular da reprodução da dominação, na qual o papel da causalidade da liberdade - para falar como Kant -, era conscientemente miniminizada, à semelhança da teoria crítica da Escola de Frankfurt, cuja sociologia crítica seguia, por outros meios, o programa de pesquisa dos anos trinta. A intensa introdução de convenções normativas pela sociologia pragmática a reconcilia com a razão prática, mas à medida que essa introdução tende a abandonar as questões do poder e da distribuição desigual (e injusta) de recursos diversos (capital econômico, social, cultural, etc.), eu me pergunto se não seria necessário integrar dialeticamente a sociologia da justificação em uma sociologia hermenêutica da dominação, capaz de perseguir desde o interior a comunicação sistematicamente 
deformada. ${ }^{9}$ Em tal perspectiva crítica, se analisariam as justificações em situação, mas sem partir da hipótese de que todos os atores dispõem de igual poder de justificação (Ramaux,1996). Ou seja, para uma atenção suplementar da justiça, o sociólogo não oporia simplesmente a justificação à dominação, mas, precisamente a fim de desativar os efeitos de poder que pesam sobre a situação de disputa e, notadamente, sobre as argumentações e os argumentos que os atores podem fazer valer, ou, ocorrendo não os fazer valer, ele analisaria em que medida a justificação é afetada desde o interior pela dominação. Incluindo assim a violência simbólica da comunicação sistematicamente deformada no modelo pragmático da justificação, a meu ver, poderíamos melhor nos dar conta dos elementos externos que manifestam suas pressões na situação e pesam sobre o desenvolvimento interno da disputa. Afinal, as situações de disputa estão longe de serem situações da palavra ideal.

Se Bourdieu depreciava as práticas, concebendo-as como epifenômenos da estrutura material, Boltanski e Thévenot, ao contrário, as elevavam, conferindo-lhes uma dignidade metafísica. Para compreender as práticas, é necessário, daqui em diante, fazer uma curva hermenêutica pelas convenções metafísicas, invocadas por pessoas comuns em situações de disputa. São elas que orientam suas práticas significativas e lhes conferem um sentido. A sociologia pragmática rompe com o "paradigma do desvelamento" dos mestres da suspeição (Marx, Nietzsche, Freud) para se ligar ao paradigma da interpretação dos hermeneutas e dos fenomenólogos, recusando invocar os mecanismos sociais e as forças inconscientes que determinariam o ator, sem ele saber, e explicariam suas ações. A sociologia da justificação apreende o ser humano como um ser livre (als freihandelndes Wesen) e religa o ponto de vista da antropologia pragmática de Kant, insistindo mais sobre o que o ser humano faz, do que sobre o que é feito dele. Diferentemente da sociologia crítica, ela toma seriamente os discursos, os princípios e os valores legitimadores que dão um sentido à ação, sem ver aí ilusões bem fundadas que, em nome de um conhecimento superior, em nome da Ciência, seria necessário submeter à crítica. Contrariamente ao mundo tridimensional da dominação, o mundo bidimensional da 
justificação é um mundo sem estruturas profundas a desvelar e sem ilusões a dissipar.

Modestamente, sem ilusões, o sociólogo reúne o mundo dos atores, não para criticá-los, nem para explicar sua ação, mas para compreendê-los, explicitando as competências das quais dão prova, quando denunciam uma injustiça. Nessa perspectiva interpretativa, explicar é "explicitar" e fazer compreender o desenrolar da ação, organizando o relato em uma trama compreensível, excluindo tanto as causas materiais quanto as reificações (Veyne, 1971, p. 111-144). Denunciar uma injustiça, desvelar realidades ocultas e desiguais, reclamar uma correção da situação e convocar a uma transformação da sociedade não é mais monopólio da sociologia crítica. Em sociedades altamente reflexivas como as nossas, em princípio, cada um dispõe de capacidades críticas e é capaz, ainda que em graus diferentes e com resultados desiguais, de denunciar uma injustiça, apoiando-se sobre trabalhos de intelectuais mediáticos. Estimando que o bom senso crítico é a coisa melhor dividida no mundo, os teóricos do senso comum democratizam a competência crítica e passam, como Ulrich Beck (1993, p. 4), da 'teoria crítica da sociedade' a uma 'teoria da autocrítica da sociedade', que se apresenta mais modestamente como uma sociologia pragmática da crítica.

A sociologia crítica - reinterpretada em concordância com o pragmatismo que recusa opor a reflexão à ação, considerandoa como uma fase no interior mesmo da ação - pode agora reunir o mundo vivido e ser tratada como uma sistematização e uma formalização das competências críticas que os atores trabalham sem o saber, mas sabendo o que fazem, quando devem explicar as razões de suas ações e as dos outros ou dar-se conta das situações nas quais eles se encontram. Entretanto, mesmo se a sociologia bourdieuniana pode ser considerada como uma formalização exemplar do sentido crítico ordinário - a tal ponto que poderíamos dizer estar ela para o senso comum, como a epistemologia está para a ciência -, ela permanece marcada por uma rigidez que destoa relativamente da flexibilidade do senso comum. Denunciando as injustiças a partir da 
perspectiva oblíqua da cidade cívica - essa 'Cidade das cidades' que não é uma cidade como as outras (Ricoeur, 1995) -, ela se apresenta, definitivamente, incapaz de passar de um registro de avaliação a um outro e de julgar as injustiças de uma maneira pluralista, se apoiando sobre diferentes esferas de justiça. A sociologia pragmática, ao contrário, pode tudo isso. Tendo renunciado à posição '(bour)divina' (Aron) de desvio, a única vantagem que ela mantém, relativamente aos atores, consiste no fato de, não estando engajada na ação, dispor de um observatório que lhe permita reconstruir o espaço estrutural das justificações possíveis. ${ }^{10}$

$\mathrm{Na}$ encruzilhada da hermenêutica e da fenomenologia, do pragmatismo e do interacionismo simbólico, da teoria dos atos de linguagem e da etnometodologia, a sociologia da justificação mostra-se como uma microssociologia da ação que coloca as práticas significativas - e notadamente as práticas constitutivas da situação -, no centro da análise. Na esteira de Habermas, Boltanski e Thévenot tomam o problema da ordem social, se a ocasião se apresenta, da coordenação das ações em situação como início (Habermas, 1984; Boltanski; Thévenot, 1991, p. 39-59, 425-431; Thévenot, 1990). A coordenação da ação pressupõe um entendimento sobre a 'definição da situação' (W. I. Thomas): Quais são os seres presentes? Como qualificá-los? Para responder a essas questões práticas, Boltanski e Thévenot introduzem as Cidades como mediações simbólicas e axiológicas que permitem constituir a situação como um conjunto bem ordenado de interações vividas entre as pessoas e os objetos que os atores encontram em seu ambiente imediato. Normalmente, esse entendimento sobre a definição da situação é tácita, não sendo necessário interromper a ação para tematizar, explicitamente, a constituição da situação enquanto tal. A situação é dada, experenciada e constituída de maneira contínua e sustentada com um contexto vivido e significativo, 'qualitativo e qualificativo' (Dewey, 1938, p. 70), de interações entre os humanos e as coisas. $\mathrm{O}$ ator faz, imediata e ingenuamente, a experiência e promove um 'andamento de comportamento' (course of behavior) (p. 67). ${ }^{11}$ Mesmo se os etnometodólogos tivessem razão em insistir sobre o 
fato massivo e incontornável de que a ordem social é sempre uma realização prática, contingente, local, endógena, natural, observável em situação (Garfinkel, 2002, p. 91-120), resta dela somente o entendimento de que, normalmente, se faz de maneira pré-reflexiva e pré-predicativa, sobre o pano de fundo compartilhado, de um mundo vivido em comum.

Ora, em certas situações - notadamente em situações de contendas -, esse acordo tácito deixa de valer. Torna-se necessário submeter, explicitamente, a constituição da situação ao que podemos chamar, com Dewey, uma 'pesquisa de senso comum'. Há 'qualquer coisa que falha' e, para superar o embaraço, os atores são obrigados a acordarem sobre os registros convencionais de avaliação para qualificar as pessoas e as coisas que constituem a situação. Como Simmel e Habermas, também Boltanski e Thévenot insistem sobre o momento consensual do debate: para disputar e discutir, é necessário ao menos estar de acordo sobre não estar de acordo e acordar em situação sobre os critérios normativos de julgamento que permitem estabelecer a realidade, no caso de contestá-la. Eles diferem de Habermas (e de Bourdieu), no registro cívico das discussões da esfera pública, porque distinguem uma pluralidade de registros de argumentação e de justificação com pretensões universais (as Cidades) que oferecem referências normativas convencionais - supostas comuns -, mediatizando a ação, permitindo aos atores julgar os outros e suas ações, apoiando-se sobre objetos, sem recorrer à violência. ${ }^{12}$

Boltanski e Thévenot insistem, como Habermas, sobre o carácter público das discussões e das disputas. Eles não o fazem tanto por razões filosóficas - referindo-se aos fundamentos da justiça -, quanto por razões sociológicas - dizendo respeito à observação e à descrição dos motivos e das intenções dos atores em situação (Boltanski; Thévenot, 1991, p. 436-438). Em lugar de compreender os motivos e as intenções verbalizadas como indícios de uma interioridade inefável, à qual teríamos acesso por empatia (Einfühlung), nos projetando na situação do Outro, como pensava 
ainda Husserl (Cefaï, 2001), eles as analisam como os modos públicos de descrição, de configuração e de relatar a ação ou, como diz C. W. Mills, se inspirando no behaviorismo de Mead e no pragmatismo de Dewey, como 'vocabulários' típicos e convencionais de motivos normativos socialmente aceitáveis que os atores invocam nos contextos de justificação. ${ }^{13}$

A sociologia pragmática ultrapassa o 'situacionismo' radical da etnometodologia e reúne a hermenêutica e a sociologia compreensiva, incluindo as Cidades como vocabulários convencionais e repertórios transituationais de justificação que os atores utilizam e introduzem em concordância nas situações de disputa para definir os termos do acordo ou do desacordo e coordenar suas ações em justiça. Para configurar a ação e agir em comum, os atores devem fazer uma volta pela cultura e beber no fundo comum das representações coletivas. Assim, graças às Cidades, são superadas as platitudes do empiricismo da etnometodologia e da teoria dos atores em rede para atingir uma construção teórica em dois estágios (individual/coletivo, particular/geral) onde se reencontram as entidades relevantes das três ontologias regionais, a saber, das pessoas humanas (das almas) em interação com os objetos e as coisas (os corpos não animados), assim como com os seres metafísicos (dos espíritos) que mediatizam as interações entre as pessoas e os objetos, permitindo situá-los 'em equivalência' e, assim, qualificá-los.

Ainda que as disputas girem, o mais freqüentemente, em torno de uma gratificação contestada e contestável dos objetos e dos recursos e os atores não possam denunciar as injustiças sem exigir ao mesmo tempo uma retribuição mais eqüitativa dos bens, é assinalável que os economistas da grandeza definam a disputa como um desacordo que se apóia, em primeiro lugar sobre a "grandeza das pessoas", e, então, sobre o carácter mais ou menos justo de sua distribuição na situação. Nas disputas, as pessoas procuram se engrandecer e diminuir as demais, tratando-as como se elas tivessem usurpado um estado de grandeza não justificado. Com efeito, ainda que os recursos e os objetos sejam levados em conta e joguem um papel primordial nas 'provas de grandeza', como veremos mais 
adiante, eles são introduzidos e concebidos, à primeira vista, não como objetos de distinção que manifestariam o pertencimento do ator a uma classe social, mas como 'instrumentos de grandeza' que os atores acionam para se atribuir valor.

Para se medir e avaliar a grandeza das pessoas, mediante os objetos que procuram no ambiente imediato, é necessária uma referência, uma forma de generalidade que, transcendendo as pessoas e as coisas particulares, permita colocá-las em equivalência e qualificar a grandeza relativa delas. Essa colocação 'em equivalência' - ou 'em relação', como diria Simmel -, das pessoas e das coisas não é automática, mas pressupõe primeiramente um 'investimento de forma' (Thévenot, 1986), que 'formata' os dados de tal modo que os elementos materialmente diferentes possam ser considerados como equivalentes e subsumidos nas categorias gerais e homogêneas. ${ }^{14}$ Resultando de tais investimentos de formas, as diferentes Cidades representam formas de investimentos gerais que funcionam como formas categoriais (Kant) ou simbólicas (Cassirer) que unificam e estruturam, de modo diferencial, os dados da experiência, captando-os em suas 'redes de significações'. Diferentemente das formas de entendimento de Kant e das formas simbólicas de Cassirer, as Cidades não são formas analíticas, mas formas sintéticas. Verdadeiros 'transcendentais históricos', elas são o resultado de uma colocação em forma coletiva, institucional e convencional que precede os indivíduos e lhes fornece os instrumentos de equivalência necessários para que eles possam se colocar em acordo sobre a unidade-referência medindo sua grandeza relativa. Transcendendo a situação, elas oferecem então os padrões da justiça que permitem aos indivíduos definir a situação de disputa e agir em comum. Então, semelhantemente, pode-se dizer com Georg Simmel (1992, p. 18) que as Cidades são 'formas de associação' (Formen der Vergesellschaftung) que estruturam as interações em situação de 'uns com, por e contra os outros'.

Enquanto convenções normativas, orientadas para o bem comum e para o interesse geral, as Cidades exprimem diferentes 
princípios históricos, mas universais, de justiça, e, para serem recebidas como legítimas, as justificações e as acusações ordinárias a eles devem fazer referência, implicitamente. As justificações e as acusações que não invocam o interesse geral e que não fazem referência a um valor socialmente aceito, tais como: a eficácia técnica, a performance econômica, a igualdade cívica, a celebridade, a confiança ou a inspiração, não são admissíveis. ${ }^{15}$ À diferença de Habermas e de Rawls, que retêm um só princípio da justiça - o princípio imparcial e republicano da universalização kantiana, própria à Cidade cívica -, mas vagamente em acordo com Walzer que pluraliza a idéia de justiça, projetando os princípios de justiça em esferas autônomas -, Boltanski e Thevenot enumeram muitas ordens axiológicas legítimas, irredutíveis e incompatíveis, abastecendo de 'vocabulários' de justificação que os atores invocam para definir a situação de disputa e coordenar suas ações. Concebidas como ordens axiológicas construídas em torno de 'princípios superiores comuns' que servem como marcos e repertórios de legitimação, são três as exigências que o modelo axiomático das Cidades formula e que toda filosofia política deve levar em conta: primo, nenhuma pessoa não pode ser excluída de uma cidade (exigência da comum humanidade); secundo, cada um pode aceder a todas as cidades (exigência cosmopolita); tertio, cada membro de uma cidade pode ser ordenado conforme um princípio de grandeza e ser qualificado de "grande" ou de "pequeno" (exigência da ordem).

Para inventariar e formalizar esses vocabulários de justificação que remetem cada um a um fim diferente da 'vida boa com e para outro em instituições justas' (Ricoeur, 1990, p. 202), eles recorreram a seis textos canônicos da filosofia política e moral e trataram suas obras como 'gramáticas do laço político' que explicitam e sistematizam as pressões argumentativas que os atores devem levar em conta para tornar suas críticas aceitáveis. Dos textos de Santo Agostinho ( $A$ cidade de Deus), Bossuet (La politique tirée des propres paroles de l'écriture sainte), Hobbes (Leviatã), Rousseau (Do contrato social), Adam Smith (A riqueza das nações) e Saint Simon (Du système industriel), retiraram seis Cidades: a cidade inspirada, a cidade 
doméstica, a cidade de renome, a cidade cívica, a cidade mercantil e a cidade industrial. ${ }^{16}$ Bem entendido, Boltanski e Thévenot não querem sugerir que os atores leram esses livros. Seu argumento consiste em dizer o que os atores dispõem, por metafísica infusa, de um conhecimento tácito de seus conteúdos, os quais eles mostram ao se referirem à inspiração e à graça, à lealdade e à tradição, à opinião e ao reconhecimento, à igualdade e à solidariedade, à competitividade e à marcha ou à eficácia e à competênca técnica para assentar um acordo ou sustentar un litígio.

À semelhança dos tipos ideais weberianos, as Cidades são utopias conceituais que não existem de fato. Na realidade, não se encontra mais anjos que almas imaculadas e puros espíritos, mas sempre situações compostas envolvendo humanos e não humanos. Inspirados pela 'revolução anti-copernicana' de Latour e Callon, que colocaram os objetos no centro da análise sociológica, Boltanski e Thévenot introduziram com força, em seu modelo, as coisas como 'instrumentos da qualificação' das pessoas, segundo uma grandeza. Retomando uma metáfora de Weber, se poderia dizer que os objetos desempenham o papel 'de orientador' que seleciona as Cidades e determina as vias da justificação, definindo a natureza das 'provas de grandeza' que permitem testar a estatura das pessoas. Os objetos podem jogar esse papel de comutador, porque, diferentemente das pessoas, os objetos são, por natureza, ligados e religados a mundos determinados. A exigência de humanidade e a exigência cosmopolítica interditam a reificação dos humanos, mas não valem para os não humanos. Pode-se ligá-los, então, sem escrúpulos, e religá-los de modo permanente às cidades e analisar a reificação, como um procedimento de resolução de conflitos. A cada Cidade corresponde todo um "Mundo comum", mobiliado de objetos, de coisas e de máquinas de todo tipo (regulamentos, diplomas, códigos, mercadorias, prédios, etc.), integrados ou não a 'Dispositivos'. Assim, tribunais eleitorais são de natureza 'cívica', enquanto os projetos são de natureza 'industrial' e as jóias de família de natureza 'doméstica'. Acionando os objetos de uma certa natureza, os atores mobilizam e determinam igualmente os repertórios de justificação 
que definem a situação e permitem determinar a grandeza das pessoas. Assim, um curriculum vitce mal preenchido, apresentado ao empregador após uma entrevista, situa o candidato ao emprego como 'pequeno' no mundo do mercado, enquanto uma carta de amor comovente define o amante como 'grande' no mundo inspirado. Ou seja, situações nas quais os objetos são ajustados às Cidades de tal modo que sua agregação constitui um mundo comum coerente, claramente definido por uma prova de grandeza bem determinada, mas podem ser subvertidos pela presença de objetos 'fasciculados' ou 'desordenados' ${ }^{17}$ (Latour), pertencentes a outras cidades, integrados a outros mundos.

A introdução parasitária de uma grandeza estrangeira por meio de um objeto mediano, previsivelmente descartável ou simplesmente desativado, serve para alavancar a crítica e relançar a disputa, mas agora como conflito entre mundos. O desacordo se funda sobre o princípio de justiça que deve regular a mensuração das grandezas e sobre o mundo no qual a prova deve ser agenciada para ser convincente. Assim, o secretário licenciado por falta profissional pode fazer valer a presença da foto de família no escritório do patrão para fazer surgir um outro mundo, introduzir um outro princípio e, assim, reverter a situação em seu favor, envolvendo um testemunho do mundo doméstico. Ao introduzir a foto de família na situação de disputa, um outro princípio de julgamento, mantido até então oculto, é desvelado e, visto da cidade doméstica, o 'grande' patrão demonstra ser, 'na verdade' um 'pequeno' déspota. Alternativamente, os atores podem aproveitar a presença de objetos fasciculados para 'demarcar um compromisso' entre os princípios de justiça, procurando um princípio superior de síntese, que integre os princípios superiores comuns e estabilize o compromisso em redes sociotécnicas sólidas. Tal empreitada - verdadeira materialização de um compromisso histórico mercantil-industrial, composta de todas as naturezas possíveis, enfraquecendo atualmente provas instituídas pelo arranjo neo-corporatista dos Trinta Gloriosos - revoluciona o mundo, transformando-o em um magma rizomático de redes sociotécnicas (Boltanski; Chiapello, 1999). Como materialização de compromissos 
marcados e de provas passadas, essas últimas permitem que as redes sociotécnicas daí resultantes - associando humanos e não humanos, valores e fatos -, se desloquem entre o micro e o macro (Boltanski; Chiapello, 1999, p. 74), funcionando assim, como ponto de passagem entre a microssociologia pragmática e a macrossociologia das transformações sociais. Considerando as provas como desligadores que permitem religar a situação de ação ao contexto mais amplo da sociedade conexionista contemporânea, a sociologia pragmática retoma algumas idéias centrais da teoria das redes. Na medida em que a análise da network society desemboca em uma crítica normativa da flexploitation mundial do neo-capitalismo contemporâneo, podese notar, com um grão de ironia, que a teoria de Callon e Latour funciona, efetivamente, como uma trégua que permitiu à sociologia pragmática uma reconciliação com a sociologia crítica de Bourdieu. Essa reconciliação ideológico-política da teoria crítica não anula a crítica pragmática da sociologia crítica, mas reconfigura-a de modo idealista. Introduzindo as visões normativas do mundo como motor das transformações sociais, ela oferece uma 'crítica corretiva' da teoria da dominação que reduz um pouco rápido demais as visões normativas a ideologias e as ideologias a distorções e dissimulações da realidade. Dando assim justiça à justiça, a sociologia pragmática, ao mesmo tempo, deslegitima a teoria dos atores em rede como uma visão a-crítica do mundo, que acompanha e performa a sociedade conexionista neo-capitalista emergente - mesmo que ela tenha permitido efetuar, metodologicamente, a ligação entre os níveis micro e macrossociológico de análise.

Resumamos: partindo de uma observação microssociológica das práticas de justificação e de denúncia agindo nos momentos críticos nos quais a ação de uns e de outros não é mais coordenada espontaneamente, a sociologia pragmática propõe um modelo que permita compreender como os atores se fixam para definir a situação, invocando os registros e os repertórios convencionais e transituacionais da justificação, orientados para o bem comum, que apresentam os instrumentos de equivalência necessários para se colocarem de acordo sobre a grandeza relativa assim que se engagem em suas provas e se apóiem sobre os objetos e as coisas integradas 
nos dispositivos. Esses dispositivos heterogêneos - resultado de provas passadas e que estabelecem a situação - podem, igualmente, introduzir novas provas e engendrar transformações sociais em dimensões que ultrapassem a situação e subvertem, duradouramente, o mundo - para melhorá-lo ou piorá-lo.

\section{Crítica da sociologia: a co-construção performativa do mundo e as redes}

Há muito economistas e empresários que falam sobre os humanos e os recursos. Tal não é o caso dos sociólogos. Ainda que Marx, Durkheim, Weber, Simmel e Mead não tenham negligenciado completamente os objetos em suas teorias e suas pesquisas, somente há pouco os artefatos fizeram sua aparição na cena sociológica (Pels; Hetherington; Vandenberghe, 2002). Devemos essa introdução dos objetos nas ciências humanas ao talento provocador de Bruno Latour, Michel Callon e John Law. Melhor conhecida sob a designação de Actor-Network Theory (ANT), a teoria dos atuantesem-rede integra, de modo original, os trabalhos de Deleuze, Serres, Greimas, Leroi-Gourhan e Simondon, em uma espécie de romance experimental metafísico, digno de um Gombrowicz, sobre a composição progressiva e performativa de um mundo comum de objetos e sujeitos, humanos e não humanos, que se co-constituem, construindo, de modo experimental, o mundo, ou - pós-modernismo reconhecido - versões do mundo. ${ }^{18}$

Situando-se resolutamente na tradição hobbesiana, a ANT reformula o problema da ordem social, incluindo aí os objetos como base que contêm as relações sociais e dá consistência à sociedade dos humanos pela reificação, preservando-a, assim, da delitescência (Callon; Latour, 1981). Sobre o fundo de uma forte desconfiança em relação aos humanos e suas capacidades comunicacionais de alcançar um acordo e, a partir daí, os sociólogos pós-modernos acusam seus colegas de tratarem os humanos como macacos, ao modo dos etnometodólogos que concebem a ordem social como uma ordem local constantemente renegociada, e de ignorar o 
papel fundamental que os objetos desempenham na estabilização dos acordos e a materialização da ordem social. Considerando que a ordem social não é, nem pode ser, puramente social, pois os humanos têm necessidade dos não humanos e devem se associar a eles para formar uma sociedade durável, Callon e Latour propõem refuncionalizar a sociologia, definindo-a não mais como ciência da sociedade, mas como 'ciência das associações' (Latour, 1984, p. 4548,229 ), ou seja, cunhando uma nova palavra, como 'associologia'. ${ }^{19}$ Ou até mesmo como 'a-sociologia', pois diferentemente de Simmel, associação não é entendida aqui como uma comunidade espiritual, como uma associação de sujeitos, conscientes de formar una unidade, uma sociedade, mas como uma associação heterogênea de sujeitos e objetos sem alma, separados do espírito objetivo.

Indicamos as paredes, as portas, as janelas, as mesas, os livros, os artigos, os rascunhos, as canetas, todos esses objetos ordinários os quais 'dispomos' e que 'mobiliam' nossa vida cotidiana, 'emolduram' nossas interações e as tornam possíveis, a antropologia da a-modernidade se questiona se a sociologia, concentrando-se sobre os humanos e os símbolos que os ligam, não seria, literalmente - mas diferentemente da filosofia -, 'sem objeto': "Os sociólogos não procurariam meio-dia às 14 horas, construindo o social com o social ou revestindo fissuras com o simbólico, quando os objetos são onipresentes em todas as situações nas quais eles buscam o sentido?" (Latour, 1994, p. 597). Eles não vêem que são os objetos que mantêm os humanos juntos (é o momento realista da reificação, representado por um 'tecnograma') como são os humanos que mantêm os objetos reunidos (é o momento construtivista da mobilização, representável por um 'sociograma')? Eles não compreendem que os objetos não são meios, mas mediadores, no mesmo nível que as Cidades são mediações simbólicas? Eles não podem abandonar seus reflexos vétero-humanistas e conceber que os objetos fazem agir e, nessa condição, podem ser legitimamente considerados como quasesujeitos, até mesmo como atores integrais?

Com um golpe de mão, esvaziando a mediação pelo espírito objetivo e os símbolos que dão um sentido à ação e estruturam as 
práticas que (re)produzem a sociedade, a a-sociologia dos atores em rede introduz os objetos como 'atuantes' (Tesnière), ${ }^{20}$ suscetíveis de individuação, que 'fazem' a sociedade e a preservam, ligando os humanos. Antropomorfizando os objetos a todo custo, Latour não comete somente um erro de categorias - para não dizer um erro ontológico -, arriscando-se a ofender humanos e humanistas em particular, mas ele reduz também os objetos a simples coisas utilitárias e instrumentais, 'subsistentes' (Vorhanden), como diria Heidegger, pertencendo ao mundo 'mercantil-industrial'. Desconhece a pluralidade das modalidades de agenciamento de humanos e não humanos, dos quais a sociologia pragmática fez o inventário (Thévenot, 1994b). Despindo-se do simbólico ('os símbolos'), a crítica da sociologia elimina, no mesmo gesto, as relações sociais entre os humanos ('o social'), as relações intersubjetivas que 'são' a sociedade, como dizia Simmel, em proveito das relações interobjetivas que 'fazem' a sociedade. Reduzindo também a relação ternária entre o sujeito (ego), o objeto e o outro (alter) a uma relação binária entre o objeto e o sujeito, a natureza e a cultura, amalgamando-se sob esse último termo a sociedade e os indivíduos (Blandin, 2002, p. 9, 105, 168 seg.), a interobjetividade usurpa o lugar da intersubjetividade, excluindo o alter ego para substituí-lo pelo alter techno.

Ainda que o A de ANT indique ser ela compreendida como uma teoria da ação, sua insistência sobre a interobjetividade, assim como a dessimbolização da realidade por ela realizada, 'descentram' a tal ponto o sujeito que podemos nos perguntar se ela ainda permanece no âmbito da teoria da ação pragmática na qual ela se inspira, extirpando os resíduos humanistas até a raiz. Atribuindo uma capacidade de ação aos objetos, integrando os não humanos na ação e 'distribuindo' a ação dos humanos sobre seu ambiente material, Callon e Latour radicalizam o modelo da teoria da 'ação situada' (Garfinkel, Suchman, Conein) e da 'cognição distributiva' (Norman, Hutchins, Kirsh). ${ }^{21}$ Assim fazendo, eles se aproximam mais e mais do pós-estruturalismo. Com efeito, a distribuição da ação sobre os objetos, os artefatos, os instrumentos, as máquinas, em suma, sobre os dispositivos materiais que substituem as mediações simbólicas, 
não evocam simplesmente as tentativas pós-estruturalistas de 'dissipar' o sujeito unitário da ação, 'disseminando' por meio da linguagem e fragmentando-a em uma miríade de 'posições de sujeito na linguagem', como dizem os lacanianos, mas deixa pensar que Callon e Latour 'traduziram' e 'transpuseram' as tropas do pósestruturalismo na linguagem da sociologia da ação, descentrando radicalmente o sujeito em benefício dos objetos. Desse ponto de vista, as 'práticas materiais' dos atuantes-objetos, dotados de intenções e capazes de agir como sujeitos, dos quais falam Pickering (1993) e Barad (1996), parafraseando Latour, aparecem como uma retomada pseudo-fenomenológica e pós-humanista das 'práticas discursivas' do pós-estruturalismo que nada mais têm a ver com a tradição da sociologia interpretativa da ação. Restam as práticas. De acordo com a crítica do representacionismo, elas são redefinidas como performances que produzem e fabricam, efetivamente, aquilo que elas, supostamente, descrevem. Como na sociologia pragmática, as práticas permanecem formadoras e constitutivas do mundo comum, mas doravante elas não são mais somente concebidas como práticas fora do campo e 'desabitualizadas', mas ainda objetivadas e vitalizadas como práticas 'dessimbolizadas', energéticas, que performam o mundo comum. Não sendo mais um mundo vivido, esse mundo comum volta a tornar-se, então, literalmente Lebenswelt.

Seguindo os atuantes pelo mundo, em todas as suas associações e dissociações, a sociologia das redes sociotécnicas analisa como os mundos se formam e se estabilizam ou se decompõem e se dissolvem, mas diferentemente de Boltanski e Thévenot, ela não leva em conta as convenções normativas que orientam significativamente as ações e permitem as coordenadas, qualificando as pessoas e os objetos em situação. Abandonando nietzscheanamente as Cidades e a Justiça ao proveito da força e das provas de força - 'Só há provas de força ou de fraqueza' (Latour, 1984, p. 177) -, a ANT recusa a 'interpretose' (Deleuze, 1996, p. 58) como uma doença de cura..$^{22}$ Se ela abandona o idealismo dos hermeneutas e dos fenomenólogos apóstatas, não se reconcilia com o materialismo dialético de Bourdieu, mesmo que o abandono das Cidades reduza a ação a uma dimensão unicamente 
"estratégica". Com Foucault (1994, III, p. 124-130), essa última é, doravante, radicalizada e compreendida em um sentido militar e marcial. Como ações estratégicas, as batalhas, ações e reações, ofensivas e contra-ofensivas procuram definitivamente conquistar o poder e ocupar o terreno por todos os meios. Se podemos dizer que a sociologia é um esporte de combate, podemos, agora acrescentar que ela é uma arte marcial...

A insistência comum sobre as estratégias, os estratagemas e as táticas de combate não podem mascarar que Bourdieu e Latour foram combatidos violentamente, por meio de pessoas que intervieram - como Bricmont ou Bouveresse -, na 'guerra das ciências' opondo o realismo ao construtivismo (Sokal; Bricmont, 1997; Bourdieu, 2001, p. 55-64). Tudo, começando pela filosofia das ciências, opõe a hipercrítica marxizante de Bourdieu à hipocrítica nietzscheana de Latour. Do mesmo modo que podemos descrever Michel Serres como o anti-Bachelard, poderíamos apresentar Bruno Latour como o anti-Bourdieu e resumir as oposições, declarando que o materialismo de Bourdieu é realista, estruturalista, racionalista e relacionista, tanto quanto o materialismo de Callon e Latour é nominalista, empirista, vitalista e conexionista. Essas diferenças epistemo-ontológicas explicam porque palavras superficialmente similares - como 'relação', 'performance', 'representação', 'portavoz', sem esquecer a etiqueta do 'realismo construtivista' que reencontramos como auto-designação por meio dos protagonistas -, assumem uma significação profundamente oposta na sociologia da inovação e na sociologia da reprodução.

Recusando definir as estruturas profundas e as forças invisíveis, substituindo os atores e levando-os a agir sem conhecimento, Latour insiste, com Boltanski e Thévenot, que a sociologia não tem mais que construir o objeto como um sistema invisível de relações que sobredetermina e explica a ação. Contra eles, acrescenta imediatamente, não se há de explicitar e interpretar como os atores não mais constituem a situação. "Experimentai, não interpreteis jamais" (Deleuze, 1996, p. 60); "Traduzi, não expliqueis jamais", tais parecem ser os preceitos metodológicos que Callon e Latour 
preparam tão logo eles 'seguem os atores' e observam de longe e do exterior, adotando a posição de observador estrangeiro, como eles compõem progressivamente o mundo, associando os humanos e os não humanos em experimentações sociotécnicas. Eliminando tanto as alturas dos idealistas e seus valores quanto as profundezas dos materialistas, a teoria das redes se mantém, como os estetas, na aparência das coisas. Reabsorvendo o espaço tri, em seguida o bidimensional, a uma só dimensão, a da phylum vital, a ANT nivela e rebaixa 'a ontologia em massa folhada' de uns e outros para reter um só plano de análise - o 'plano da imanência' (Deleuze) ou o 'plano da dança' (Nietzsche) - onde os seres mais heterogêneos (Deus, o vento, os humanos, os animais, as coisas, etc.) se reencontram, se confundem e se agrupam na noite caosmática, que está na origem da criação dos mundos.

O mundo não é a totalidade dos fatos, mas uma concatenação infinita, concreta e quase viva de humanos e não humanos em devir, que se co-constituem, construindo um mundo em comum. Assim poderia se anunciar a primeira proposição do Tractatus scientificopoliticus do colaborador do CSI. Em seu tratado de sociologia experimental, Bruno Latour escolheu, entretanto, uma outra, mais nietzscheana, mais afirmativa em sua rejeição jubilante dos sistemas da filosofia primeira que, desconhecendo a diferença e a alteridade, reduzem tudo à unidade e à identidade: «1.1.1. Nenhuma coisa é, por si mesma, redutível ou irredutível a qualquer outra. [...] Nada se reduz a nada, nada se deduz de nada do outro, tudo pode se aliar a tudo » (Latour, 1984, p. 177 e 182). Desenvolvamos: nada se reduz a nada, pois tudo é complexo, complicado, composto, ambivalente, diferente, suplemento. Nada se deduz de nada, pois não há totalidade, nem verdade, nem essências, nem substâncias sobre as quais poderíamos erigir um sistema. Nada é dado, pois tudo pode ser desconstruído. A Sociedade, a Natureza, a Cultura, a Ciência, a Política, a Religião, a Economia, o Direito, etc., ${ }^{23}$ tudo isso não existe e, seguindo o imperativo anti-categórico, sobretudo não no singular e capitalizado ou no estado puro, sem corte, mistura, acoplamento ou aliança. Nada pode existir por si mesmo, mas tudo pode se aliar e deve se associar a tudo, tudo está para se refazer 
e reconstruir. Tudo, todo um mundo de humanos (os cientistas, os político, os marinheiros-pescadores, os deficientes, etc.) e de nãohumanos (os micróbios, os criados, os navios portugueses, EDF, as vieiras, as palavras, etc.) podem ser associados, interessados, mobilizados, enrolados, encadeados e alinhados pela força ou pela astúcia, tradução ou traição, delegação ou representação em uma rede rizomática de atuantes em devir. Sem escrúpulos e sem efetuar uma distinção de natureza entre a Natureza e a Cultura ou a Sociedade, a teoria dos atuantes em rede religa os seres mais heterogêneos em uma cadeia sociotécnica que se propaga através do espaço e, assim fazendo, constrói progressivamente o mundo como seu próprio contexto e seu próprio meio associado.

Com efeito, mesmo que os objetos técnicos em Simondon (1958, p. 50-65) mediatizem a relação entre o homem e seu ambiente por 'adaptação-criação' de um meio técnico-geográfico associado quase vivo que os condiciona como eles são condicionados por ele, as redes sociotécnicas se constituem ao mesmo tempo em que constituem o mundo. ${ }^{24}$ Como mediação entre o humano e a natureza, a rede sociotécnica é um mediador híbrido que não coloca somente os elementos em relação, mas os performa e os transforma, mediatizando-os. ${ }^{25}$ Filosoficamente falando, é uma relação primeira. Ela tem, como diz ainda Simondon (1964, p. 68), 'valor de ser'. A relação não liga os elementos quando eles são já constituídos (interrelação). Os relata não pré-existem à relação, mas como operação, a relação os constitui como entidades que emergem da relação, como dos relata, internamente religados (intra-relação). Nessa perspectiva performativa, não se trata tanto de 'ver as relações entre as coisas', quanto, como diz tão bem Marilyn Strathern (1996, p. 19), de 'ver' 'as coisas como relações'. Ver coisas como relações, isso quer dizer ver que as coisas são ontologicamente o que elas são graças à relação que as constituem por intro-ação dos elementos, pois ver que é a mediação que as fabrica e as produz, por metalepse, como origem presumida da relação. Pensar a relação de modo performativo, é pensar transversalmente a partir do meio e pensar a relação como mediação constitutiva que transforma e performa os relata, inserindo-os em um contexto relacional. Assim, para tomar um 
exemplo trivial, mas representativo da 'filosofia empírica' holandesa, a prescrição que liga o médico ao paciente asmático intervém como um atuante que transforma o paciente e o médico, integrando-os em uma rede operatória. Prescrevendo um tratamento diferente a seus pacientes asmáticos, ele os trata diferentemente. Esas práticas diferentes não tratam, entretanto, somente das doenças diferentes, mas, aparentemente, elas produzem e performam também asmas diferentes e acreditam mesmo, a crer no autor, pulmões diferentes (Willems, 1998).

Retomemos a oposição entre a Natureza e a Cultura ou a Sociedade. As redes sociotécnicas que as colocam em relação funcionam como mediadores e performadores da relação que transformam e performam a Natureza e a Cultura ou a Sociedade conjuntamente, de modo que essas jamais são dadas, e jamais separadamente, mas sempre co-construídas, co-constituídas e coproduzidas conjuntamente pela intra-relação e 'entre-captura' dos termos como dos efeitos de uma rede heterogênea emergente. O que Latour (1991, p. 110) exprime como "Natureza e Sociedade não são mais os termos explicativos, mas aquilo que requer uma explicação conjunta". Desde que compreendamos que a Natureza e a Sociedade são conjuntamente co-constitutivas na e pela operação que as mediatiza e que co-produz ou performa a realidade, compreendemos igualmente porque não se pode mais explicar a vida em sociedade pela Sociedade, como queria Durkheim. Continuamente construída e produzida pelos humanos e não humanos, a sociedade não é terminus a quo, mas terminus ad quem: "A sociedade não é o que nos reúne, mas o que é reunido. As ciências sociais tomaram o efeito pela causa, o passivo pelo ativo, o colado pela cola" (Latour, 1986, p. 276).

Redefinida como ciência das associações e das dissociações as mais heterogêneas, a sociologia é refuncionalizada em tecnologia, ciência experimental da sociotécnica ou, se quisermos, 'gênio heterogêneo' (ingenium heterogenesis). Com efeito, religando os seres em um tecido sem costura, a associologia não busca somente misturar experimentalmente as regiões ontológicas clássicas (os 
humanos, os animais e as coisas), mas, igualmente, superar a 'grande divisão', pretensamente modernista, entre a ciência ou a técnica, de um lado, e a política ou a moral, de outro. Para os sociólogos da Escola de Mines, fazer ciência, é fazer política ou, como diz Latour (1984, p. 257), girando o pensamento de Clausewitz, 'a ciência é a política continuada por outros meios'. Fazer política é forjar coalizões e fazer co-existir seres, redesenhar o coletivo e mudar o mundo, se necessário, indo ao encontro do senso comum e revolucionando a ontologia - precavendo-se de que novas associações e múltiplas conexões sejam criadas: "O múltiplo, é necessário construí-lo" (Deleuze; Guattari, 1980, p. 13). A sociologia das inovações, sob a influência nietzscheana das redes rizomáticas que deslocam a vontade de poder para a tecnologia, louva o gênio criador de empreendedores e de inovadores técnicos. Baseando-se no pragmatismo, no vitalismo e no futurismo de um 'vitalismo técnico', a sociologia das inovações se inscreve no prolongamento da tradição literária que, indo de Júlio Verne a Marinetti e Junger, entusiasmada com a vitalidade das técnicas, descreve com admiração o surgimento de novos seres heterogêneos e insólitos que perturbam nossas categorias de percepção ordinárias (Dodier, 1995, p. 29-47). A meio-caminho entre a micro-história e a grande metafísica, a 'cientificização' latouriana se apresenta como uma etnografia literária, 'infra-reflexiva' (Latour), 'multi-situada' (Marcus) e 'combinatória' (Dodier), que se propõe seguir os atores que configuram e performam tecnicamente o mundo como seguimos e construimos uma história, que prolifera como um romance.

A partir de um desvio da nova sociologia anglo-saxônica das ciências (Bloor, Collins, Mulkay, etc.), a ANT propõe um modelo original para estudar a construção (social) da realidade pelas ciências e técnicas. Para construir uma rede sociotécnica que resista, é necessário mobilizar e associar tantos atuantes (humanos e não humanos, sociais e técnicos) quanto possível, interessá-los e traduzir seus interesses de modo que eles se engagem e, uma vez engajados e inscritos, é necessário estabilizar e consolidar a rede construída, ligando duravelmente e, se possível, irreversivelmente, os atuantes - 
de objetos técnicos a fatos científicos -, de tal sorte que a associação seja materialmente aprisionada em um dispositivo que funciona como uma 'caixa preta', da qual não necessitamos considerar os conteúdos. Para analisar a passagem progressiva da construção social do coletivo para traduzir a sua reificação em um dispositivo sociotécnico, partamos de um pequeno atuante, um pequeno Príncipe, que se associa a outros atuantes e traduz os interesses deles para associálos a seu projeto e dissociá-los de outro, se possível. Traduzindo seus interesses, ele os desloca e transforma, capturando-os em seu projeto, inevitavelmente, ele se deixa, ao mesmo tempo, capturar nos projetos desses atuantes que, mesmo mobilizados e aprisionados, continuam a agir por sua própria conta. À medida que o projeto se forma e se transforma em quase-objeto, os atuantes vinculam-se a ele como os jogadores de rugby estão ligados à bola assim que lhe passem, nas constelações moventes. Traduzindo os interesses dos atuantes que captura e vincula a seu projeto, o pequeno Príncipe fala em nome deles e, como diria Bourdieu, também em lugar deles. Falando em lugar deles, ele torna-os presentes e, re-presentando-os e aos interesses deles em seu projeto, ele se engrandece e se torna um ator coletivo, capaz de falar com uma só voz e de agir como um só homem. Veja Hobbes e seu Leviatã, contratualmente autorizado a falar e a agir em nome de todos. Ou Pasteur que se exprime em seu laboratório em nome dos micróbios. Ou, ainda, Bourdieu que, movido pelo desejo de dar a palavra àqueles que não têm nem documentos, nem palavra, torna-se o porta-voz dos dominados, assim como das estruturas de dominação. Falando em nome da vontade coletiva ou, como diriam Boltanski e Thévenot, invocando maquiavelicamente 'grandezas' para se engrandecer, os pequenos atores tornam-se, progressivamente, grandes atores. Quer se trate de Hobbes, Pasteur ou Bourdieu, do ponto de vista da sociologia da tradução, esses grandes autores podem ser considerados como porta-vozes que, situados no cume de uma rede de caixas pretas empilhadas, funcionam como caixas vocais personalizadas que amplificam a palavra dos pequenos atores.

Analisando como os atores se engrandecem, traduzindo a vontade dos outros, a sociologia da tradução torna-se uma sociologia 
política das redes de porta-vozes. Falar em nome e no lugar dos outros, é torná-los presentes e re-presentá-los, simplificando a complexidade e reduzindo a multiplicidade, se possível, à unidade. É a esse ponto que as ciências intervêm na história da construção da realidade, pois os cientistas em aventais brancos, também eles, são os porta-vozes que falam em nome da natureza que não fala, como se sabe, 'por ela mesma', ainda que ela se expresse na linguagem da ciência. Para falar em nome das coisas, é necessário mobilizá-las e concentrá-las em um ponto, no caso o laboratório que se torna, então, um 'ponto de passagem obrigatória' (PPO), funcionando como um 'centro de cálculo' (Latour, 1987, p. 215-257). Para estudar os objetos reunidos no laboratório, é necessário registrar sua presença, seus movimentos e visualizar o todo nas cartas, diagramas, estatísticas ou outros meios de inscrição que permitem reduzir as coisas a variáveis manipuláveis e calculáveis, mantendo a forma das coisas invariáveis (Latour, 1985). Para manter a forma das coisas, apesar de suas diferenças materiais, é necessário um trabalho quase industrial contínuo de investimento nas formas (Callon; Law, 1985, p. 87-107), que coloca as coisas em equivalência e permite efetuar, por transferência e transporte da forma imutável, uma tradução e uma resolução contínua das palavras e das coisas. Por projeção das variações sobre um plano de referência estável, passamos assim, sem qualquer solução de continuidade, "do visível ao lisível" (Serres, 1974, p. 15-72), depois que o mundo é, efetivamente reduzido a um texto, se ele não for de papel. ${ }^{26}$ As coisas, representadas em um texto científico, podem ser mobilizadas, politicamente, como aliadas pelos pesquisadores que falam em seu nome e constróem o mundo, associando os humanos e os não humanos em redes sociotécnicas sempre mais extensas e sempre mais sólidas. Como a razão de outrora, o mundo não é um dado, mas uma tarefa. É necessário construí-lo, produzi-lo, fabricá-lo, mobilizando as coisas, os fatos e as palavras para fazê-lo pronunciar-se. Fabricado e, portanto, real, nisso nada há de contraditório, desde que compreendamos que o mundo não é mais pressuposto, mas continuamente 'performado' e transformado, reificado e realizado pelas associações e conexões que os cientistas estabelecem, criando assim uma ilhota de ordem 
no meio do arquipélago - como a senda no poema de Machado: 'Caminhante não há caminho, o caminho se faz ao andar. Caminhando se constrói o caminho, e, olhando para trás, vemos a ladeira que jamais voltaremos a pisar. Viajante, não há caminho, mas um sulco no mar' (Canto XXIX, Provérbios e canções).

Construir uma rede rizomática - ou como diz atualmente Latour, se inspirando em Isabelle Stengers, um 'Coletivo em expansão' -, eis a missão da nova ecologia política científica. ${ }^{27} \mathrm{~A}$ política do religamento consiste em experimentar, em estabelecer sempre mais conexões e associações entre os humanos e os não humanos, até que, no final do percurso, tudo e todo o mundo seja, harmoniosamente, reunido na luta política em uma rede hegemônica heterogênea que cobre o mundo inteiro. Assim formulado, o trabalho de totalização por associação dos atuantes em uma só e gigantesca sociedade anônima aparece como um trabalho de mundialização. Latour (1999, p. 270), entretanto, é preciso: "o singular da palavra coletiva não quer dizer que ela exista só”. Não estando ligado a um território ou a uma população determinada, mas a alguma visão de extensão e de estabilização sociotécnica do 'Coletivo em expansão', cada um dos coletivos busca se totalizar e se mundializar, um pouco como as empresas multinacionais que querem conquistar o mercado mundial, se especializando, uma em produtos alimentares, outra em computadores, outra, enfim, na produção automobilística. Diferentemente do sistema, que totaliza buscando o fechamento, a rede se desterritorializa e se mundializa, aspirando à abertura. Essa busca de abertura explica porque a rede não pode ser representada em sua totalidade, pois se estendendo, se associando a outros atores que encontra no caminho, cria, pouco a pouco, novas conexões funcionais, estabelecendo assim uma solidariedade técnica entre os seres mais heterogêneos (Dodier, 1995, p. 88-96). Topologicamente, a rede é um espaço complexo e complicado. Nela - como em uma carta dobrada ou em um lenço - 'cada ponto pode e deve ser conectado a não importa qual outro' (Deleuze; Guattari, 1980, p. 13), de tal modo que os atuantes mais distantes possam, de repente, se encontrar aproximados (minha colega brasileira em uma nota de 
pé de página, o microprocessador coreano em meu computador ou o pescador ligado à linha, graças ao peixe, ao oceanólogo em seu escritório), enquanto outros, vizinhos, permanecem distanciados e podem mesmo ser ejetados se eles não preenchem mais função na rede. Para essa 'compreensão-distanciamento' (Harvey-Giddens) do espaço-tempo, as práticas locais são topologicamente religadas às relações sociais mundiais, de modo que 'situações locais são influenciadas pelos acontecimentos que ocorrem muito distantes de lá e, inversamente (Giddens, 1990, p. 64), como se pode ver, por exemplo, que o emprego dos trabalhadores filipinos da Nike depende mais da venda dos tênis nos Estados Unidos do que das ações diretas da gestão local.

Vimos que uma rede sociotécnica se constrói e se consolida por associação e representação, dando voz àqueles que não a tem, começando pelos não humanos. Excluídos da sociedade, mas incluídos no 'Coletivo em via de expansão', a ANT quer estender a democracia aos não humanos, reunindo-os em uma assembléia. É uma idéia um pouco bizarra, subentendida na proposição de instaurar um 'Parlamento de coisas' (Latour, 1994), concebido sobre o modelo da 'mesa redonda', cara a Dewey (1927), mas também a Habermas e Ulrich Beck, em torno da qual políticos, cientistas e cidadãos se reúnem com o objetivo de chegar a um consenso pragmático sobre os meios e os fins da política - ou como diz Latour, sobre o 'bom modo de compor o mundo'. Nessa assembléia, os não humanos seriam forçosamente representados pelos humanos que falariam com competência em nome deles, como fazem os cientistas, os tecnólogos e os tecnocratas, mas também os industriais e os consumidores, assim que um produto novo é lançado. O objetivo das discussões da assembléia seria decidir e, decidindo democraticamente, autorizar e legitimar a construção e a produção de redes sociotécnicas hegemônicas. Assim, seria possível imaginar sessões onde os especialistas reunidos debateriam a melhor maneira de produzir carros, produtos de beleza ou a pintura. Pouco importa. O que importa, é que a eleição dos representantes ocorra sobre bases funcionais e técnicas, e não populacionais e sociais, que eles 
representem as circunscrições diretamente interessadas na matéria e que eles exprimam a opinião de todos aqueles que estão diretamente implicados. Assim, por exemplo, o Senhor Peixe, especialista da dinâmica dos bancos de peixes, não pode transpor a entrada se ele não pôde se fazer entender pelos pescadores. Inversamente, um representante dos pescadores não poderá aí participar sem dar prova de que ele pode implantar uma experiência sobre a diminuição dos bancos de peixe que satisfaça também aos ictiólogos (Latour, 2003). O que é verdade sobre os peixes deve ser, igualmente, para os pássaros e os cachorros, as árvores e as flores, os carros e as bicicletas, etc. $\mathrm{Na}$ assembléia, o Senhor Peixe apresenta uma proposição honesta para a Senhora Flor, enquanto esta negocia com o Senhor VTT. À medida que as negociações progridem e as proposições se articulam, se alonga a lista dos seres com os quais é necessário compor o mundo comum, enquanto o texto prolifera como um hipertexto, no qual tudo é religado a tudo, por um laço virtual. Ao fim, quando todos os coletivos estão reunidos e todos os textos religados sobre o plano da imanência, há somente um mundo desterritorializado - o Império. "É um universo enfeitiçado, pervertido. Um mundo sem acima, nem abaixo, onde o Senhor Capital e a Senhora Terra, caracteres sociais ao mesmo tempo que simples coisas, dançam sua dança macabra" (Marx, 1983, p. 838). ${ }^{28}$

\section{Conclusão}

Seguindo uma dialética descendente - das estruturas materiais de Bourdieu às alturas ideais de Boltanski e Thévenot e às platitudes de Latour e Callon -, apresentamos rapidamente o estruturalismo genético de Bourdieu, como um pensamento racional e relacional que confere prioridade às estruturas. Mostramos que o desvio objetivista da teoria dos campos e dos habitus tende a esvaziar as capacidades reflexivas de que dispõem os atores e a reduzi-los a simples agentes. A sociologia da crítica de Boltanski e Thévenot permite retificar ou ratificar a sociologia crítica. Ela introduz com força as mediações simbólicas que são as Cidades e, segundo a 
ANT, concebe os Dispositivos como comutadores que estabelecem o laço com a macrossociologia. Eliminando ao mesmo tempo as estruturas materiais e ideais que configuram a ação, a ANT se fixa nas práticas que performam o mundo, associando os humanos e os não humanos, em um tecido sem costura e sem fim que cobre o mundo. Seria necessário, então, inverter a perspectiva e propor uma dialética ascendente que, partindo das práticas associativas da ANT, integre os símbolos que dão um sentido à ação e permitem retificar a tendência à reprodução das estruturas de dominação cara à sociologia crítica. Inversamente, a retomada da hermenêutica no interior de uma teoria crítica das sociedades contemporâneas permitiria superar a oposição entre a sociologia da dominação e da justificação. O resultado de uma tal elevação construtivista-realista seria uma teoria hermenêutico-dialética da sociedade que analisaria o tempo presente em uma perspectiva crítica que reúne a reflexão epistemológica de seus pressupostos à crítica social das injustiças.

\section{Notas}

1 No Colóquio de Cérisy, dedicado aos trabalhos de Luc Boltanski e Laurent Thévenot, fui tentado a uma tal comparação dos "grandes sociólogos" franceses, não diretamente, mas passando pela sociologia da arte e da música e, especialmente, contrastando a sociologia da singularidade de Nathalie Heinich e a sociologia das mediações de Antoine Hennion.

2 Conforme Peirce (1959, p. 2.205), se poderia chamar à primeira 'Critik'

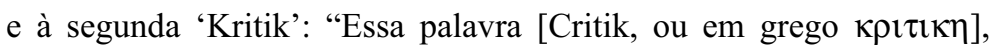
utilizada por Platão (que divide todo o conhecimento entre a epitática e a crítica), foi adotada em latim pelos Ramistas - seguidores de Pierre Ramus que, em 1551, sustentou polêmica criticando a tradição aristotélica com a divisão dos campos da dialética e da retórica (N. da T.) - e em inglês por Hobbes e Locke. Tomando-a de empréstimo de Locke, Kant, que sempre escreveu Critik - o c sendo, possivelmente, uma reminiscência de sua origem inglesa - a introduziu no alemão. Kant expressou claramente o desejo de que não se confunda essa palavra com aquela da crítica, com a crítica literária (Kritik em alemão)". 
3 Essa classificação combina as categorias de 'invenção' e de 'interpretação' que encontramos em Walzer (1987) com as de 'construção' e de 'reconstrução' que utiliza Honneth (2000). A introdução do hegelianismo de esquerda por Honneth permite corrigir a apresentação enviezada da crítica social de Walzer. Com um bom manejo da interpretação - "há somente uma via em filosofia moral" (Walzer, 1987, p. 21), o comunitarista americano não somente descartou a via da 'descoberta' e da 'invenção', mas, sem dizê-lo, rebateu a crítica dialética sobre a crítica hermenêutica. Eliminando o trabalho propriamente sociológico, que consiste em analisar a sociedade como um conjunto de sistemas e de estruturas, em um mesmo golpe ele reduziu a teoria crítica à crítica jornalística dos intelectuais engajados.

4 Diferentemente de Passeron (1994), o co-autor do manual de epistemologia sociológica que compreende a teoria do conhecimento sociológico em um sentido fraco, compatível com uma pluralidade de teorias sociológicas, Bourdieu logo concebeu-a em um sentido forte, como um Manifesto da escola, talhado sob medida de sua própria teoria sociológica do mundo social.

5 É necessário registrar que a idéia estava no ar. Podemos reencontrála tanto entre os estruturalistas, quanto entre os fenomenólogos que influenciaram o jovem Bourdieu. Assim, Lévi-Strauss (1955, p. 44-45) escreveu: "Para atingir o real, é preciso primeiro recusar o vivido, reintegrá-lo, a seguir, em uma síntese objetiva, despojada de toda sentimentalidade". Mais explícito, Merleau-Ponty (1964, p. 31) afirma: "A exclusão [da intencionalidade] é, aliás, somente provisória: a ciência reintroduzirá, pouco a pouco, o que inicialmente descartou como subjetivo. Integrará, porém, como caso particular das relações e dos objetos que, para ela, definem o mundo".

6 De um ponto de vista metateórico, a insistência sobre a reprodução, quase automática, das estruturas de dominação pela interiorização deixa pensar ser Bourdieu mais do que Habermas ou Honneth o mais digno sucessor de Adorno. Assinalo que a teoria crítica de Habermas é bem melhor aceita na França por sociólogos e teóricos da ação do que a sociologia crítica de Bourdieu, que provoca reações epidérmicas violentas, mesmo que ambos focalizem a comunicação e o poder, analisando-os a partir de um ângulo diferente. Para Habermas, a situação ideal da palavra é caracterizada pela ausência de poder, enquanto para 
Bourdieu é a ausência de comunicação sem violência simbólica que define o poder. A insistência comum sobre a comunicação (com e sem constrangimentos) é o que torna uma leitura cruzada de Habermas e Bourdieu possível e potencialmente fecunda.

7 A ligação ao presente deu lugar à recusa do 'presentismo' (Laborier; Trom, 1993). Em defesa do pragmatismo, gostaria de destacar que a história pode muito facilmente ser reintroduzida na situação de dois modos. Insistindo com Koselleck e Foucault sobre a mudança conceitual que afeta o uso da linguagem em situação ou considerando com Foucault e Latour os Dispositivos como sedimentações materiais do passado. Em seguida, Boltanski e Chiapello (1999) responderam à crítica e, explicitamente, reintroduziram a dimensão histórica no modelo pragmático pelo viés das transformações históricas das estruturas ideais que organizam as provas materiais.

8 Mais radicalmente pragmático e menos personalista que Boltanski, Thévenot (1998) privilegia as práticas em detrimento dos indivíduos e das pessoas e acaba por reunir as conclusões pós-humanistas dos nietzscheanos. Optando resolutamente por um nível de análise "aquém da figura do indivíduo autônomo" (p. 133), que aparece como um efeito performático das práticas. Desconstruído pragmaticamente, o indivíduo aparece in fine como "uma figura relativa a um mundo cultural ocidental" (p. 137), prestes a se desfazer como uma figura na areia.

9 Desde o interior, como diz tão bem Ricoeur (1986, p.413), 'uma hermenêutica das profundezas é ainda uma hermenêutica'. Para um trabalho exemplar de uma tal hermenêutica crítica, remeto a Kögler (1992).

10 Em sua sociologia da arte e da literatura, Nathalie Heinich (1998) conjuga muito bem a construção estrutural do espaço das posições possíveis e a interpretação do sentido da ação, demonstrando assim que as duas posturas podem ser muito bem combinadas em uma sociologia interpretativa na terceira pessoa.

11 “O que é designado pela palavra 'situação' não é um objeto ou um acontecimento isolado nem um conjunto de objetos e de acontecimentos simples. Porque nós não experenciamos e não formamos julgamentos sobre objetos e acontecimentos isolados, mas somente em conexão com um conjuto contextual. Esse último é o que se chama uma 'situação", (Dewey, 1938, p. 66). 
$12 \mathrm{O}$ regime da justificação pública é um regime de ação entre outros. Em seguida à publicação De la justification, Boltanski e Thévenot exploraram, cada um por seu lado, diferentes regimes de ação. Em L'amour et la justice comme compétences, Boltanski (1990, p. 110116) distingue quatro regimes pragmáticos de ação: o amor, a justiça, a justeza e a violência. Em oposição ao regime teleológico da ação consciente, Thévenot explorou, em uma série de artigos, diferentes modalidades de coordenação da ação: da coordenação local de regimes de ação à conveniência pessoal (1990) e da familiaridade (1994a) com os regimes mais convencionais da justificação (1990), do direito (1992) e do plano (1995).

13 "Os motivos são as justificações aceitas por programas ou ações passadas, presentes ou futuras" (Mills, 1940, p. 907). Considerando os motivos como os vocabulários de justificação, Boltanski e Thévenot dão uma 'torsão pragmática' à fenomenologia para evitar os problemas ligados à introspecção e à intropatia. Assim, eles permanecem, entretanto, ligados ao cognitivismo da fenomenologia husserliana e consideram as normas e os valores não de modo normativo, como o fizeram Scheler, Parsons e Habermas, mas de modo cognitivo, como o fazem Husserl, Mills e Luhmann.

14 Nos anos oitenta, Thévenot passou progressivamente da codificação das categorias socioprofissionais (1981) para os investimentos de formas (1986) e, generalizando e pluralizando esses últimos, ele chegou às cidades (1988-1991). Retrospectivamente, nos damos conta de que os investimentos de formas, que seria necessário aproximar das tecnologias de governo estudadas por Nikolas Rose, eram concebidos originalmente como formas pertencentes à cidade industrial.

15 A exemplo da filosofia política liberal, a sociologia da justificação insiste sobre o fato de que os argumentos, as críticas e as justificações não são admissíveis e legítimas a não ser que se orientem para o bem comum e possam pretender à universalidade. $\mathrm{O}$ universalismo da sociologia difere, entretanto, do universalismo da filosofia, ao não relevar o a priori, mas resultar de uma análise empírica das 'condições de felicidade' das acusações: "Os denunciadores devem, então, para escapar à singularidade, realizar as conexões muito fortes e se ligar aos outros em um nível mais elevado de generalidade (por exemplo, invocando os grandes princípios humanitários, a justiça em geral, os direitos humanos, etc.)" (Boltanski, 1984, p. 22). 
16 O número das Cidades não é determinado de uma vez por todas, pois antigas cidades podem desaparecer e novas cidades podem emergir por síntese e compromisso. Ao lado de seis repertórios oficiais de justificação, Lafaye e Thévenot (1993) esboçaram os contornos de uma 'cidade ecológica', enquanto Boltanski e Chiapello (1999) introduziram em seu grande livro sobre o capitalismo pós-fordista a 'cidade por projetos'. A análise comparativa de repertórios de justificação permitem destacar a existência de variações nacionais na utilização dos princípios da justiça (Lamont; Thévenot, 2000). Ainda que todas as Cidades estejam presentes no toolkit cultural de franceses e americanos, os autores constatam que os últimos, mais liberais, privilegiam a performance do mercado nas avaliações da desigualdade racial, a arte, a literatura ou a natureza, enquanto os primeiros se mantêm republicanos até o final.

17 No original, «chevelus» ou «échévelées». [N. da T.].

18 Em uma crítica do pós-humanismo ambiente e de seus laços com o biocapitalismo, explorei as bases vitalistas da filosofia neo-nietzscheana da tecnologia tipicamente francesa, mostando o que o conexionismo latouriano deve a Deleuze, Serres e Cia.

19 O autor faz um jogo entre os neologismos "associologia" - estudo das associações, amplamente - e "a-sociologia" - ausência de sociologia, em um contexto em que as associações ganham uma decodificação específica, conforme explica essa passagem do artigo. [N. da T.]

20 Retomada por Greimas e popularizada em seguida por Latour, a noção semiótica de atuante foi introduzida por Lucien Tesnières e definida como um elemento do laço verbal: "O laço verbal exprime todo um pequeno drama. Como um drama com efeito, ele comporta obrigatoriamente um processo, e quase sempre, atores e circunstâncias. [...] Os atuantes são os seres ou as coisas que, a um título qualquer e de qualquer modo que seja, mesmo ao título de meros figurantes e do modo mais passivo, participam do processo" (Tesnières, 1959, p. 102).

21 Há excelente discussão em torno dessas questões em Quéré (1997).

22 Alternativamente, poder-se-ia interpretar a teoria dos atuantes rizomáticos na perspectiva da sociologia pragmática da justificação e ler Callon e Latour e os outros autores da rede como os gramáticos políticos da Cidade conexionista mundial neo-capitalista em vias de emergir. 
Nessa perspectiva, se poderia considerar os Cosmopolitiques de Isabelle Stengers (1996-97) ou Politiques de la nature de Bruno Latour (1999), como textos canônicos do laço político. Se hesito, entretanto, em situar Latour e Stengers na tradição de Rousseau e Santo Agostinho, é por causa de seu amoralismo intempestivo. Boltanski e Chiapello notaram bem que as teorias contemporâneas da complexidade reticular nada têm a fazer com a transcendência das convenções normativas: "[Elas] são construídas explicitamente contra as construções metafísicas do bem comum ... de modo a evitar, a contornar ou a tornar endógena a posição ocupada por uma instância moral, de onde poderiam derivar os julgamentos legítimos se referindo à justiça" (Boltanski; Chiapello, 1999, p. 226).

23 A antropologia da modernidade que nos propõem Latour e Callon visa enfraquecer o pensamento moderno e mostrar que somos todos 'primitivos modernos' (Latour, 1991). Como os pré-modernos, nós misturamos sempre, sem confessá-lo, Natureza e Cultura em NaturasCulturas inextricáveis. Aquilo que começou como uma antropologia simétrica das ciências e das técnicas se transformou, em seguida, em uma antropologia sistemática das formas ocidentais da veracidade com fabricação de coletivos, todos azimutes. A Ciência, a Política, a Economia, a Religião e o Direito já foram objeto de uma desconstruçãoredescrição atuante.

24 Tomo emprestado os termos da co-constituição e da co-produção da realidade de Hennion (1993), mesmo que ele fale de mediação para teorizar a operação do que Callon e Latour chamam, após Serres, tradução ou translação. Quanto aos pós-estruturalistas, eles não falam de mediação nem de tradução, mas da articulação para desenhar "toda prática que estabelece uma relação entre os elementos de tal sorte que sua identidade é modificada como resultado da prática articulatória" (Laclau; Mouffe, 1985, p. 105).

25 Introduzida por Austin para descrever os atos de linguagem que performam a realidade que eles descrevem (quando dizer, é fazer), a noção de performatividade foi retomada e generalizada a seguir por Austin, Derrida, De Man e Rorty para atacar a teoria representacional da verdade: as teorias, os discursos, a linguagem não refletem e não representam a realidade, mas são atuantes e agentes que a produzem e a performam. A sociologia da ciência (Woolgar, Latour, Mulkay, 
Ashmore, Mol, etc.) operacionaliza a noção de performatividade, mostrando como os cientistas produzem, constróem e fabricam a realidade social em seus laboratórios. Como queer theorist, Butler inova a teoria da performatividade, ligando-a às teorias da performance teatral (performance studies).

26 Boa parte da etnofilosofia de Latour, da obra escrita com Woolgar que o tornou célebre até seu último livro sobre o direito, pode ser considerada como uma aplicação brilhantíssima da teoria serreseana-leibniziana da tradução das variações fenomenais em um texto científico. $\mathrm{O}$ artigo sobre o 'Pedófilo de Boa Vista' (freqüentemente reproduzido) oferece uma bela ilustração fotográfica do trabalho de tradução contínua por transferência da forma para uma cascata de imagens.

27 Dando um torneamento neo-gramsciano à cosmopolítica, poderíamos descrever a construção do coletivo em expansão como formação contínua e infinita de um bloco histórico heterogêneo (Laclau; Mouffe, 1985). Nessa perspectiva pós-estruturalista, a política do coletivo hegemônico em expansão aparece como uma política de identidade que procura estabelecer, por articulação ou tradução dos interesses e das demandas concretas dos diferentes movimentos sociais (feminista, ecologista, anti-racista, etc.), relações entre diferentes grupos subalternos e a construir, assim, progressivamente, o 'bloco histórico' como uma formação hegemônica contingente e militante que une a natureza e o espírito, a base e a superestrutura, em uma "unidade de oposições e de distinções", como dizia Gramsci.

28 Privilegiei uma leitura mercantil-industrial da competição dos mundos uma vez que uma leitura mais política-cívica, nos moldes da democracia experimental de Dewey, da mesma forma que uma leitura mais inspirada, religiosa, budista por assim dizer, seriam igualmente possíveis, embora eu creia que para Latour, como para Pierre Lévy (2000), um outro deleuziano, a união entre o capitalismo e o budismo somente seria possível numa filosofia mundana do mundo sublunar.

\section{Construction and criticism in the new French Sociology}

Abstract: This article considers a comparative analysis of the sociologies of Bourdieu, Boltanski \& Thévenot, and Latour \& Callon.

Following a descending dialectic of the Bourdieu material structures 
to the ideal heights of Boltanski and Thévenot and to the platitudes of Latour and Callon, the author primarily displays Bourdieu's genetic structuralism as a rational and relational thinking, which establishes a priority to the structures. He shows that the objectivist deviation of the theory of the fields and habitus tends to empty the reflexive capacities in which the actors are reduced into simple agents. In a second moment, the author shows that the Boltanski's and Thévenot's sociology of criticism allows to rectify or to correct the critical sociology. It introduces the symbolic mediations that are the Cities and conceive the Devices as commutators, which reestablish the link with the macrosociology. Finally, the author criticizes the elimination of the material and ideal structures that configure the action for the sociology of the actors in net. The action fixes itself in the practices that perform the world, associating human beings and the not human, in a never-ending fabric that covers the world.

Key-words: Bourdieu, Boltanski, Latour, critical sociology, pragmatic sociology, theory of the actors in net, social, critical construction.

\section{Referências bibliográficas}

ALEXANDER, J. C. La réduction: Critique de Bourdieu. Paris: Cerf, 2000.

BARAD, K. Meeting the Universe Halfway: Realism and Social Constructivism without Contradiction. In: HANKINSON, L.; NELSON, J. (Eds.). Feminism, Science and the Philosophy of Science. Dordrecht: Kluwer, 1996. p. 161-194

BECK, U. Die Erfindung des Politischen: Zu einer Theorie reflexiver Modernisierung. Francfort sur le Main, Suhrkamp, 1993.

BENATOUÏL, T. Critique et pragmatique en sociologie. Quelques principes de lecture. Annales HSS, 2, p. 281-317, 1996.

BERGER, P.; LUCKMANN, T. The social construction of reality: a treatise in the Sociology of Knowledge. London: Allen Lane, 1967.

BLANDIN, B. La construction sociale par les objets. Paris: PUF, 2002.

BOLTANSKI, L.Les usages sociaux du corps. Annales, 26, 1, p. 205-233, 1971. 
BOLTANSKI, L. Les cadres: la formation d'un groupe social. Paris: Minuit, 1982.

. La dénonciation. Actes de la Recherche en Sciences sociales, 51, p. 3-40, 1984.

. L'amour et la justice comme compétences: trois essais de sociologie de l'action. Paris: Métailié, 1990.

BOLTANSKI, L.; THEVENOT, L. De la justification: les économies de la grandeur. Paris: Gallimard, 1991.

BOLTANSKI, L.; CHIAPELLO, E. Le nouvel esprit du capitalisme. Paris: Gallimard, 1991.

BOURDIEU, P. Structuralism and the Theory of Sociological Knowledge. Social Research, 35, 4, p. 681-706, 1968.

. Esquisse d'une théorie de la pratique. Genève: Droz, 1972.

. Le sens pratique. Paris: Minuit, 1980.

. Leçon sur la leçon. Paris: Minuit, 1982.

. Science de la science et réflexivité. Paris: Raisons d'agir, 2001.

Ein soziologischer Selbstversuch. Francfort sur le Main: Suhrkamp, 2002.

BOURDIEU, P.; CHAMBOREDON, J.-Cl.; PASSERON, J.-Cl. Le métier de sociologue. Paris : Mouton, 1973. (A profissão de sociólogo: preliminares epistemológicas. Trad. Guilherme João de Freitas Teixeira. Petrópolis: Vozes, 1999).

CALLON, M.; LATOUR, B.Unscrewing the Big Leviathan; or how actors macrostructure reality, and how sociologists help them to do so? In: KNORR, K.; CICOUREL, A. (Eds.). Advances in Social Theory and Methodology. Londres: Routledge, 1981. p. 277-303

CALLON, M.; LAW, J. La protohistoire d'un laboratoire. In: CALLON, M. (sous la dir. de). La science et ses réseaux: genese et circulation des faits scientifiques. Paris: La Découverte, 1985. p. 66-116.

CEFAÏ, D. L'enquête de terrain en sciences sociales: Phénoménologie, pragmatisme et naturalisme. In: BENOIST, J.; KARSENTI, B. (sous la dir. de). Phénoménologie et sociologie. Paris: PUF, 2001. p. 43-64. 
CHATEAURAYNAUD, F. La faute professionnelle: une sociologie des conflits de responsabilité. Paris: Métailié, 1991.

CORCUFF, P. Les nouvelles sociologies: constructions de la réalité sociale. Paris: Nathan, 1995.

DELEUZE, G.; GUATTARI, F. Mille plateaux: capitalisme et schizophrénie 2. Paris: Minuit, 1980.

DELEUZE, G.; PARNET, C. Dialogues. Paris: Flammarion, 1980.

DESROSIERES, A.; THEVENOT, L. Les catégories socioprofessionnelles. Paris: La Découverte, 1988.

DEWEY, J. The public and its problems. New York: Holt, 1927.

Logic: the theory of inquiry. New York: Holt, 1938.

DODIER, N. Agir dans plusieurs mondes. Critique, xlvii, 529-530, p. 427$458,1991$.

Les appuis conventionnels de l'action: elements de pragmatique sociologique. Réseaux, 62, p. 63-85, 1993.

Les hommes et les machines: la conscience collective dans les sociétés technicisées. Paris: Métailié, 1995.

DOSSE, F. L'empire du sens: l'humanisation des sciences humaines. Paris: La Découverte, 1995.

FOUCAULT, M. Il faut défendre la société (1977), In: Dits et écrits, III. Paris: Gallimard, 1994. p. 124-130.

GARFINKEL, H. Ethnomethodology's Program: working out Durkheim's Aphorism. Lanham: Rowman and Littlefield, 2002.

GAUCHET, M. Changement de paradigme en sciences sociales. Le Débat, 50, p. 165-170, 1988.

GIDDENS, A. The consequences of modernity. Cambridge, UK: Polity Press, 1991.

GOFFMAN, E. Interaction ritual. New York: Garden City, 1967.

HABERMAS, J. Erkenntnis und Interesse. Francfort sur le Main: Suhrkamp, 1968.

Erlaüterungen zum Begriff des kommunikativen Handelns. In: HABERMAS, J. Vorstudien und Ergänzungen zur Theorie des kommunikativen Handelns. Francfort sur le Main: Suhrkamp, 1984. p. $571-606$ 
HEINICH, N. Ce que l'art fait à la sociologie. Paris: Minuit, 1998.

HENNION, A. La passion musicale. Une sociologie de la médiation. Paris: Métailié, 1993.

HONNETH, A. Rekonstruktive Gesellschaftskritik unter genealogischem Vorbehalt. Zur Idee der 'Kritik' in der Frankfurter Schule. Deutsche Zeitschrift fur Philosophie, 48, 5, p. 729-737, 2000.

KÖGLER, H.-H. Alienation as Epistemological Source: Reflexivity and Social Background after Mannheim and Bourdieu. Social Epistemology, 11, 2, p. 141-164, 1997.

LABORIER, P.; TROM, D. Historicités de l'action publique. Paris: PUF, 2003.

LACLAU, E.; MOUFFE, C. Hegemony and Socialist Strategy. Londres: Verso, 1985.

LAFAYE, C.; THEVENOT, L. Une justification écologique? Conflits dans l'aménagement de la nature. Revue Française de Sociologie, 34, 4, p. 495-524, 1993.

LAHIRE, B. La variation des contextes en sciences sociales: remarques épistémologiques. Annales HSS, 2, mars-avril, p. 381-407, 1996.

LAMONT, M.; THÉVENOT, L. (Eds.). Rethinking Comparative Sociology: Repertoires of Evalution in France and the United States. Cambridge, UK: Cambridge University Press, 2000.

LATOUR, B. Les microbes: guerre et paix. Suivi de Irréductions. Paris: Métailié, 1984.

. Les vues de l'esprit: une introduction à l'Anthropologie des Sciences et des Techniques. Culture technique, 14, p. 4-30, 1985.

. The powers of association. In: LAW, J. (Ed.). Power, action and belief: a new Sociology of Knowledge? Londres: Routledge, 1986. p. 264-280.

LATOUR, B. Science in action: how to follow scientists and engineers through society. Milton Keynes: Open University Press, 1987.

. Nous n'avons jamais été modernes: essai d'anthropologie symétrique. Paris: La Découverte, 1991.

. Une sociologie sans objet? Remarques sur l'interobjectivité. Sociologie du Travail, 4, p. 587-607, 1994. 
LATOUR, B. Esquisse d'un parlement des choses. Ecologie Politique, 10, p. 97-115, 1994.

Politiques de la nature: comment faire entrer les sciences en démocratie. Paris: La Découverte, 1999.

A nouveaux territoires, nouveau Sénat. Le Monde, 10 janvier 2003.

LEVI-STRAUSS, C. Tristes tropiques. Paris: Plon, 1955.

LEVY, P. World philosophie. Paris: Odile Jacob, 2000.

MARX, K. Das Kapital: Kritik der politischen Oekonomie, Dritter Band, dans Marx-Engels Werke, Band XXV. Berlin: Dietz Verlag, 1968.

MERLEAU-PONTY, M. Le visible et l'invisible. Paris: Gallimard, 1964.

MILLS, C. W. Situated actions and vocabularies of motive. American Sociological Review, 5, p. 904-913, 1940.

PASSERON, J.-Cl. De la pluralité théorique en sociologie: theorie de la connaissance sociologique et théories sociologiques. Revue Européenne des Sciences Sociales, 32, 99, p. 71-116, ANO 1994.

PEIRCE, C. S. Collected papers. Cambridge: Harvard University Press, 1960. Volume II: Elements of Logic.

PELS, D., HETHERINGTON, K.; VANDENBERGHE, F. The status of the object: performances, mediations and techniques. Theory, Culture and Society, 19, 5/6, p. 1-21, 2002.

PICKERING, A. The mangle of practice: agency and emergence in the Sociology of Science. American Journal of Sociology, 99, p. 559$589,1993$.

QUERE, L. La situation toujours négligée? Réseaux, 85, p. 163-192, 1997.

RAMAUX, C. Les asymétries et les conflits sont-ils solubles dans la cognition? Une lecture critique des Economies de la grandeur. Economies et Sociétés, Série D, 2, p. 71-84, 1996.

RICOEUR, P. Herméneutique et critique des idéologies. p. 367-417, In: Du texte à l'action: essais d'herméneutique II. Paris: Seuil, 1986

. Soi-même comme un autre. Paris: Seuil, 1990.

. La pluralité des instances de justice. In: RICOEUR, P. Le juste. Paris: Editions Esprit, 1995. p. 121-142. 
SCHATZKI, T. Practice Theory. In: SCHATZKI, T., KNORR-CETINA, K.; VON SAVIGNY, E. (Eds.). The practice turn in contemporary theory. Londres: Routledge, p. 1-15.

SIMMEL, G. Soziologie. Untersuchungen über die Formen der Vergesellschaftung. Francfort sur le Main: Suhrkamp, 1992.

SIMONDON, G. Du mode d'existence des objets techniques. Paris: Aubier, 1958.

L'individu et sa genèse physico-biologique. Paris: PUF, 1964.

STRATHERN, M. The Relation. Cambridge, UK: Prickly Pear Press, 1996.

SOKAL, A.; BRICMONT, J. Impostures intellectuelles. Paris: Odile Jacob, 1997.

STENGERS, I. Cosmopolitiques. Paris: Les Empêcheurs de Penser en Rond, 1996-97. 7 volumes.

TESNIERE, L. Eléments de syntaxe structurale. Paris: Klincksieck, 1959.

THEVENOT, L. Les investissements de formes. In: THEVENOT, L. (Ed.). Conventions économiques. Paris: PUF, 1986. p. 21-71.

THEVENOT, L. L'action qui convient. In: PHARO, L.; QUERE, L. (sous la dir. de). Les formes de l'action: Semantique et Sociologie. Paris: E.H.E.S.S, 1990. p. 39-69.

. Jugements ordinaires et jugements de droit. Annales ESC, 6, p. 1279-1299, 1992.

Le régime de familiarité: des choses en personne. Genèses, 17, p. 72-101, 1994a.

Objets en société: suivre les choses dans tous leurs états. Alliage, 21, p. 74-87, 1994b.

L'action en plan. Sociologie du travail, 3, p. 411-434, 1995.

Pragmatiques de la connaissance. In: BORZEIX, A.; BOUVIER, A.; PHARO, P. (sous la dir. de). Sociologie et connaissance: nouvelles approches cognitives. Paris: CNRS Ėditions, 1998.

VANDENBERGHE, F. Une histoire critique de la sociologie allemande: alienation et réification. Paris: La Découverte, 1997-1998. 2 tomes. 
VANDENBERGHE, F. The real is relational: an epistemological analysis of Pierre Bourdieu's Generative Structuralism. Sociological Theory, 17, 1, p. 32-67, 1999.

- Reconfiguration et rédemption des acteurs en réseaux. Critique humaniste de la sociologie actantielle de Bruno Latour. Revue du MAUSS, 17, 1, p. 117-136, 2001.

Sociology: new theoretical developments. In: KUPER, A.; KUPER, J. (Eds.). The Social Science Encyclopedia. 3 ed. Londres: Routledge, 2004. v. 2, p. 980-983.

VEYNE, P. Comment on écrit l'histoire: essai d'épistémologie. Paris: Seuil, 1971.

WALZER, M. Interpretation and Social Criticism. Cambridge: Harvard University Press, 1987.

WILLEMS, D. Inhaling Drugs and Making Worlds: The Proliferation of Lungs and Asthmas. In: BERG, M.; MOL, A. (Eds.). Differences in Medicine: unraveling practices, techniques, and bodies. Durham: Duke University Press, 1998. p. 105-118. 